\title{
THE INDONESIAN MILITARY'S LAST YEARS IN EAST TIMOR: AN ANALYSIS OF ITS SECRET DOCUMENTS
}

\section{Samuel Moore}

If we subtract from reality the illusory perspective on it, we lose reality itself.

Slavoj Žižek

In its retreat from East Timor after the referendum of August 30, 1999, the Indonesian military managed to remove or destroy nearly all of the documents that it had accumulated over the twenty-four years of the occupation. This must not have been an easy feat since the military, ABRI (Angkatan Bersenjata Republik Indonesia), was a vast machine for generating records, everything from inventories of food rations to classified daily intelligence reports. The ABRI bureaucracy had offices, storerooms, closets, even bathrooms, stacked full of documents in every district. The military's scorched earth operation certainly quickened the Herculean task of eliminating many of these documents. The troops and their East Timorese irregulars burned down most military buildings along with about 70 percent of all other buildings in the first three weeks of September. Nevertheless, no matter how well-organized the evacuation and extensive the burning, the military was fated to leave some documents behind. There

\footnotetext{
* I would like to thank the staff of Yayasan HAK in East Timor, especially the director Aniceto Guterres, for allowing me to consult the Indonesian military documents in their possession. I would also like to thank Matthew Jardine, Peter Carey, and Douglas Kammen for their comments on a draft of this article.
} 
were bound to be units that did not have time, amid all their other duties, to take care of that final detail, and bound to be buildings that the arson squads skipped over. In launching such a quick evacuation, the military was to be inevitably betrayed by the assiduity of its own record-keeping.

East Timorese human rights workers of the organization Yayasan HAK, returning to the capital city of Dili in the weeks after the arrival of the Australian-led international forces in late September, discovered several large caches of secret documents left behind in military offices. They brought these documents to the house where they were staying and refused to release them to the Australian military despite threatening demands from several officers. They have, however, opened them for inspection to researchers such as myself. From hereon, I will refer to this cache of documents as the HAK Collection. The authenticity of the documents is beyond question: there are tens of thousands of pages bearing the seals and signatures of a great variety of officers over many years. Moreover, most documents do not incriminate the military in any crimes and merely testify to the mundane character of much of its work. There are no documents that could fuel a major exposé about the massacre of villagers or the torture of prisoners.

What is perhaps surprising is that much of the information in these secret documents is largely in accord with the government's propaganda. The military was holding to its own propaganda line within its internal communications. Most observers, on seeing that the propaganda was so transparently fraudulent, have assumed that the military was fully aware of the reality and was consciously manufacturing lies for public relations purposes. What the HAK Collection indicates is that while officers did indeed lie or conceal the truth in some cases (such as the army's funding, arming, and directing of the militias in 1999), they were trapped in their own myths and repeatedly understood facts according to their own fictions. Over the course of the occupation, the military constructed a set of myths that were not just for public consumption but were essential for imparting a sense of purpose and a righteous esprit de corps among the troops. It is doubtful that ABRI could have sustained the occupation without reassuring myths to support the moral correctness of its acts. Its intelligence agents, whose work is well represented in the HAK Collection, collected information to confirm their myths and disregarded contrary data.

The Indonesian government's public justifications for the occupation are wellknown; it developed a fairly elaborate mythological narrative that purported to explain the necessity and legality of the invasion of 1975 and all subsequent military operations. According to the official line, the guerrillas were mere bandits and terrorists; the vast majority of the populace was either loyal to Indonesia or too intellectually backward to care who governed them; the act of integration of East Timor in 1976 was legal and just; Indonesia had won popular support by lavishly spending the central government's money and improving the living standards of the people; and whatever discontent remained was caused by unjustified feelings of economic deprivation. ${ }^{1}$ Since the Indonesian mass media faithfully relayed this official

\footnotetext{
${ }^{1}$ By my non-comprehensive listing, the Indonesian government issued fourteen publications in Indonesian and English concerning the "progress" of East Timor and the insignificance of the resistance. The most ambitious in this genre was Dua Puluh Tahun Timor Timur Membangun (Twenty Years of Development in East Timor) (Dili: Indonesian Civil Servants Corps, 1996).
} 
line, it shaped the Indonesian public's understanding of the war in East Timor. One of the most experienced scholars of Indonesia, Herb Feith, observed in 1993: "The media acknowledge that dissatisfaction exists, especially among high school graduates, reflecting discrepancies between educational output and employment opportunities. But they maintain that most of the dissatisfied people are sensible enough to realize that Indonesian authority is irreversible-all except a tiny minority of foreigninfluenced troublemakers." 2

The Suharto regime viewed the East Timorese as it did Indonesians, as a "floating mass" (massa mengambang), a mindless public that could be easily swayed and manipulated, and could not therefore be trusted with democracy. ${ }^{3}$ Since the regime believed the East Timorese to be more backward than most Indonesians, it felt even more justified in lording over them and denying them their basic human rights. After all, the East Timorese were not considered to be fully human. All the colonial tropes emerged full-blown in the New Order's public discourse about East Timor: a childlike populace that had been stuck in Stone Age-ignorance for centuries was being brought into the modern world by the benevolent civilizing mission of a more advanced nation. As Benedict Anderson has pointed out, Indonesia's leaders, unable to imagine the East Timorese as full members of the Indonesian nation, viewed them in the way that the Dutch colonizers used to view Indonesians. ${ }^{4}$

One should not assume that these myths sufficiently describe the consciousness of the Indonesian military officers occupying East Timor. Any officer with a modicum of intelligence had to wonder why, after years of large-scale counterinsurgency operations, the military was unable to eliminate all armed resistance in such a tiny territory with a population one-twelfth of Jakarta's. If most East Timorese were supposed to be loyal to the nation, why did the army need to impose a pervasive system of surveillance in every village and neighborhood? If the East Timorese were so mentally backward, why was it so difficult to defeat the resistance? The military could not frankly admit to itself that much of the population was secretly and cleverly conspiring against it by sending food, supplies, information, and fresh recruits to the guerrillas.

The officers were caught in a kind of doublethink. To admit to themselves that the enemy was virtually the entire population would have contradicted the justifications for the occupation, yet not to admit that fact would have led to the erroneous belief that a pervasive military presence was unnecessary to hold the half-island. The officers could not sustain the occupation without a fairly realistic assessment of the enemy. They could not develop effective strategies to defeat the resistance on the

\footnotetext{
2 Herb Feith, The East Timor Issue Since the Capture of Xanana Gusmao (Sydney: East Timor Talks Campaign, 1993), p. 11.

3 The term "floating mass" was coined by one of Suharto's closest associates, Maj. Gen. Ali Murtopo, in his book Akselerasi Modernisasi Pembangunan 25 Tahun (Jakarta: CSIS, 1972), pp. 95-96. He justified what he called the "depolitization" of the populace: "...generally, the people, most of whom live in the villages in a mental world that is not yet sufficiently rational, have been helplessly tossed about and caught up in political conflicts and narrow ideologies ..." The term "floating mass" signified a naturally apolitical people who were better off if detached from political parties. Curiously, for a book that had very few English words, the term "floating mass" appeared in English without translation.

4 Benedict Anderson, "Imagining East Timor," Arena 4 (April-May 1993).
} 
illusory assumption that their enemy was merely a small band of 147 guerrillas and fifty civilian sympathizers (the army intelligence count in 1991). The military's documents exhibit the fuzzy thinking of an officer corps desperately wanting to believe in the state propaganda and simultaneously dimly aware of the falsity of it. Deluded by its own myths, the Indonesian military never fully understood the nature of its enemy - and this ultimately, as I will argue below, contributed to its own undoing.

\section{The Army's Knowledge of the Resistance}

One would imagine from reading the army's secret intelligence reports of the 1990s that the guerrillas were roving gangs of criminals who subsisted on what they stole from the peasantry. According to a 1991 report, "The activities of the guerrillas have been limited recently to stealing the property of the people." 5 The army usually used the term "Security Disturbance Group" (Gerakan Pengacauan Keamanan, abbreviated as GPK) for them instead of their official name, Falintil: Armed Forces of National Liberation of East Timor (Forcas Armadas de Libertacao Nacional de Timor Leste). According to the army's reports, the people did not voluntarily supply the guerrillas, and the guerrillas themselves had no principled political agenda, or, if they did have a political agenda, it was communist, which in the lexicon of the New Order was synonymous with evil. At times, the army referred to the insurgents as the forces of the "communist/Marxist and Leninist Fretilin party," despite the fact that Falintil, after 1987, did not belong to Fretilin (or any political party), and Fretilin was neither communist, Marxist, nor Leninist. ${ }^{6}$

According to the army, the only East Timorese who had a principled commitment to independence were no more than a handful of men, a hardcore clique leftover from the pre-1975 generation. This clique managed to delude the youth, many of whom had been imperfectly educated by East Timor's still rudimentary school system. The discontented, easily impressionable students, the drop-outs and unemployed, constituted the support base for the pro-independence cause. As for students,

. . because they do not understand integration and the meaning of independence, whether as a result of being left out of the integration process or a lack of proper explanation, in addition to their youth and high hopes and desire for a better life, they are easily influenced by issues and propaganda so that consciously or unconsciously, they want to stage anti-integration demonstrations.?

Except for these misguided youth, the rest of the society was content under Indonesia's military rule: "In general, the society no longer has a problem with integration and those who do not agree with integration are actually just a small part of the society, a product of social jealousies and the difficulties of finding employment. ${ }^{\prime 8}$

\footnotetext{
${ }^{5}$ Kodam IX Kolakops, Rencana Operasi “Halo Kapaz" (August 31, 1991; Secret), introductory text, p. 5.

${ }^{6}$ Ibid., appendix C; appendix G, p. 1.

7 Ibid., appendix E, p. 3. .

8 Ibid., introductory text, p. 3.
} 
The army entered the 1990s full of confidence that the resistance had been defeated. President Suharto opened up East Timor to foreigners in 1989 on the presumption that whatever counterinsurgency warfare persisted could be kept safely isolated from the foreign visitors in the cities. The army knew that the guerrillas were no longer a serious military threat, as they were up to the early 1980 s, but found it impossible to eliminate the remnants still surviving as small, highly mobile units in the forested hills. It should come as no surprise that army officers did not know how many guerrillas existed-if they knew the exact number they would have had enough information to locate and defeat them. After all, Falintil was not a conventional army with a fixed number of soldiers; members of the clandestine civilian network temporarily stayed in the camps during times of great repression, such as the period following the 1991 Santa Cruz massacre. It is surprising, however, that army intelligence supplied estimates of the number of guerrillas that pretended to be precise and that these estimates were consistently on the low side. In a report of 1992, army intelligence estimated the number of guerrillas to be 241, only 130 of whom were armed; in 1995, it reported the existence of 210 guerrillas holding ninety-eight weapons; in 1999, it estimated that five hundred guerrillas were living in the hills. ${ }^{9}$ If the army actually believed these estimates, it deluded itself into thinking the army was much smaller than it was. The number of guerrillas became definitively numerable once they were grouped into a single cantonment near the town of Alieu after the Australian-led international force arrived in late 1999. There were about 1,500 guerrillas who took up residence in the camp. The Falintil commander, Taur Matan Ruak, stated that nine hundred of them were experienced fighters who had been part of the resistance for many years, while six hundred had joined in 1998, presumably because of the greater freedom that resulted after Suharto's fall in May of that year. Thus, there were in 1999, for example, three times as many guerrillas as the army reported. ${ }^{10}$

Although the army believed that the guerrillas and the clandestine resistance constituted a small minority of the population, it also appears to have believed that they were remarkably powerful. A 1992 report outlining the overall plan of army operations in East Timor contains a table titled "Data on Disturbed Villages" (Data Desa Rawan) that classifies East Timor's 442 villages into three colors: green, yellow, and red. There is no explanation accompanying the table about the meaning of this color classification. One can presume that the colors marked the degree to which the villages were "disturbed": green meant the absence of any disturbance, yellow meant partially disturbed, and red meant seriously disturbed. If this was indeed the meaning

${ }^{9}$ Kodam IX Kolakops, Rencana Operasi "Halo Kapaz," appendix C, p. 5; Kodam IX Kolakops, Perintah Operasi "Tuntas-I" (April 1992; Secret), appendix C, p. 5; Kepala Tim Analis Intelijen, "Rekapitulasi Kekuatan Personil dan Senjata GPK Fretilin" (Dili, October 1995; Secret); Korem 164, Rencana Operasi "Wira Dharma-99" (Dili, July 1999; Secret), p. 3.

10 Personal communication, Virgilio Guterres, March 4, 2001. Talitakum (Dili), "Sayonara Falintil," February 21-28, 2001. "Guerilla veterans transformed into regular recruits," Sydney Morning Herald, February 2, 2001. One of the regional commanders, David Alex, told a journalist who courageously trekked to his camp in 1996 that Falintil had six hundred guerrillas, which is about three times more than the army's estimate of the previous year. Matthew Jardine, "The US-Indonesia Alliance Against East Timor," The Christian Science Monitor, January 14, 1997. 
of this color-coding, the table reveals that the army considered only one-third of the villages ( 37 percent) as peaceful and secure.

Table 1

Army Classification of the Security Status of Villages in East Timor, 1992

\begin{tabular}{|l|c|c|c|c|}
\hline Military District & Green & Yellow & Red & Total \\
\hline Dili/Kodim 1627 & 14 & 5 & 14 & 33 \\
\hline Baucau/Kodim 1628 & 16 & 35 & 7 & 58 \\
\hline Los Palos/Kodim 1629 & 10 & 12 & 12 & 34 \\
\hline Viqueque/Kodim 1630 & 4 & 19 & 11 & 34 \\
\hline Manatuto/Kodim 1631 & 16 & 12 & 1 & 29 \\
\hline Aileu/Kodim 1632 & 15 & 14 & 2 & 31 \\
\hline Ainaro/Kodim 1633 & 9 & 12 & 8 & 29 \\
\hline Manufahi/Kodim 1634 & 8 & 10 & 11 & 29 \\
\hline Kovalima/Kodim 1635 & 19 & 1 & 1 & 21 \\
\hline Bobonaro/Kodim 1636 & 15 & 36 & -- & 51 \\
\hline Ermera/Kodim 1637 & 14 & 26 & 12 & 52 \\
\hline Liquisa/Kodim 1638 & 18 & 5 & -- & 23 \\
\hline Ambeno/Kodim 1639 & 5 & 13 & -- & 18 \\
\hline Total & 163 & 200 & 79 & 442 \\
& $(37 \%)$ & $(45 \%)$ & $(18 \%)$ & $(100 \%)$ \\
\hline
\end{tabular}

Source: Kodam IX Kolakops, Perintah Operasi "Tuntas I" (1992), appendix D, sub-appendix I, "Data Desa Rawan."

The strength of the resistance lay in its constant motion. Like nearly everyone in East Timor, the army knew the names of the guerrilla leaders, such as Xanana Gusmao, David Alex, Sabica, Lere Anan Timur, Ular, and Falur. But the army did not know exactly where they were. Intelligence reports on Xanana, for instance, put him in the Ainaro region in August 1991 when in fact he had been living in Dili, right under their noses, since February 1991. Military intelligence officers finally discovered by March 1992, at the latest, that he had shifted his base out of the mountains, but they still did not realize that he was living full-time in Dili itself. They thought he was living in the hills south of Dili and only occasionally entering the city. In late July 1992, intelligence was complaining that the army could not locate Xanana, though he had managed to conduct three interviews with foreign journalists, two of which took place in Dili itself. $^{11}$

In the years after the 1991 Santa Cruz massacre, the clandestine network became the army's number one priority. This network was not just organizing demonstrations and sending information to foreign countries, it was guaranteeing the survival of the guerrillas. Intelligence knew that Falintil's strategy was not to win battles and forcibly

${ }^{11}$ Kolakops, Perintah Operasi "Tuntas I," appendix C, p. 12; Kepala Tim Analisis Intelijen kepada Panglima Kolakops, Memo R/60/MI/VII/1992, July 28, 1992. On Xanana's actual whereabouts, see the book written by a member of the clandestine network in Dili who was in contact with him: Constancio Pinto and Matthew Jardine, East Timor's Unfinished Struggle (Boston: South End Press, 1997). 
drive the Indonesian army from the territory: "... the head of the Security Disturbance Group (Xanana) changed strategy in 1983 and expanded the network in the cities through the Clandestine Front. ${ }^{12}$ Intelligence correctly understood that Falintil simply wanted to survive, to prove to the world that East Timor's integration was still contested. The clandestine network, therefore, was "the most important factor in continuing the Security Disturbance Group's struggle because it continually supplies logistic support to the Security Disturbance Group in the forests (the Military Front). "13 The army thought that it had almost entirely destroyed the clandestine network in the crackdown after the Santa Cruz massacre: "the repressive actions of the Government of the Republic of Indonesia have broken up a large part of the Clandestine network, both inside and outside East Timor . . ."14 According to the head of the Intelligence Analysis Team, a branch of the national-level agency BAIS (Badan Intelijen Strategis) in East Timor, the army had succeeded, at least temporarily, by August 1992: "the Clandestine Front is not yet bold enough and does not yet feel it has the capacity to take actions, so they prefer to stay quiet for the moment while continually trying to regather their strength and regroup their network and wait for the best chance to launch an action. ${ }^{15}$

Though confident of being able to wreck the clandestine network, the army perceived it as an elusive, ghost-like creature. As the head of the Intelligence Team lamented six months after the Santa Cruz massacre, "At the moment it is very difficult to detect the activities of the GPK and the activities of its Clandestine front." ${ }^{16} \mathrm{He}$ was impressed with the organizational skill of his adversaries: "the clandestine network has a well-organized cut out system [cell system] and the selection of personnel is very rigorous, as is the holding of meetings that are well-organized so that other people are not allowed entrance."17

Army intelligence ventured no estimates on the number of people in the clandestine network in 1991 and could define its composition only in vague terms: "students, youths, civil servants, and other members of the society." ${ }^{18}$ In April 1992, intelligence ambitiously attempted to list every person in East Timor who supported independence and came up with the names of 872 "anti-integration" individuals. ${ }^{19}$ By the mid-

\footnotetext{
12 Kepala Tim Analis Intelijen, kepada Panglima Kolakops, Memo Intelijen nomor R/63/MI/VIII/1992, August 11, 1992. In a different memo, the same intelligence officer dated the change in strategy to 1985. resistance to recreate the clandestine network and the army's success in detecting its members. The Intelligence Analysis Team, according to a diagram of the army structure in the 1992 Perintah Operasi "Tuntas I" report, was directly under the Kolakops commander. Going by a draft letter requesting a larger budget in 1992, it received funding from BAIS (Badan Intelijen Strategis) headquarters in Jakarta, employed thirty-two agents, and owned one computer and one video camera. Lt. Kol. P. Napitupulu, Surat kepada Wakil Kepala BAIS ABRI, "Permohonan Penambahan Biaya," March 1992.

16 Kepala Tim Analis Intelijen, kepada Komandan Kopassus, Memo nomor R/43/MI/IV/1992, April 21, 1992.

17 Kepala Tim Analisis Intelijen, kepada Panglima Kolakops, Memo R/60/MI/VI/1992, July 28, 1992.

18 Kodam IX Kolakops, Rencana Operasi "Halo Kapaz," introductory text, p. 6.

19 Satuan Tugas Intelijen, "Daftar Nama-Nama Anti-Integrasi" (Dili, April 1992; Secret).
} 
1990s, the army officers apparently sensed that the clandestine network was more extensive than they had imagined. The head of the Dili district command estimated, in April 1997, that there were about 1,500 members of the clandestine front in Dili alone. Still, he dismissed them as a collection of malcontents, "frustrated people, intellectuals, students, Catholic figures, and social figures. ${ }^{\prime 20}$ A year later, the same command compiled a list of 129 names of individuals it believed to be a part of the clandestine front in Dili. ${ }^{21}$ In 1999, intelligence estimated that there were six thousand members of the clandestine network in all of East Timor. ${ }^{22}$

Army officers were worried about the clandestine network because it seemed, in their view, so clever in manipulating the naive East Timorese into joining it. They believed that the blandishments of the resistance frequently proved irresistible to the East Timorese, even those serving as soldiers in the Indonesian army. An intelligence officer recalled previous experiences of mass desertions:

It is still remembered about the tactics for spreading the Clandestine Security Disturbance Group whose structure reaches down to the lowest level (the village level), that is Cernak and Nucleo, how it entered into the state apparatus and pitted people against each other, around 1983-84, and finally many Wanra [civil militia] fled to the forest. If this becomes the goal of the growth of the Clandestine network, it means that the Milsas [irregular East Timorese privates] that are at the Kodims [district-level army commands] can become a target of the Clandestine GPK." 23

When East Timorese recruits deserted, leaked documents, or rebelled, the army did not conclude that their actions reflected popular resentment against the occupation. Instead, the army interpreted such behaviors as evidence of the remarkable ability of the pro-independence clique to manipulate and deceive their fellow East Timorese.

According to military intelligence, the guerrillas were bandits, their clandestine supporters were social misfits, and the rest of the society was blissfully content thanks to the material benefits Indonesia had brought to East Timor. Traces of a contrary interpretation emerge in a list of questions that the army requested the intelligence agents to investigate. Certain questions appear to recognize that the society as a whole was not so loyal: "Do the people still hate the Indonesian military? Why?" Another question indicates that the military officers knew that the East Timorese were trying to

${ }^{20}$ Lt. Col. Soenarko, Commander Kodim 1627, Perintah Operasi "Maluk-II" (Dili, April 1997; Secret), appendix $B$.

21 Kodim 1627 Intelligence Staff, "Daftar Nama-Nama Clandestin Sewilayah Kota Dili" (Dili, May 23, 1998; Secret). The Kodim for Dili had twenty-one soldiers and officers in its intelligence staff, most of whom were sergeants. Kodim 1627, Intelligence Section Officer, "Daftar Nama-nama Personil Intel Kodim 1627 Dili" (Dili, May 1998; Secret).

22 Korem 164, Rencana Operasi "Wira Dharma-99," p. 3.

${ }^{23}$ Lt. Col. P. Napitupulu, Kepala Tim Analis Intelijen, kepada Panglima Kolakops, Memo Intelijen nomor R/63/MI/VIII/1992, August 11, 1992. In this quote, as in others, I have tried to convey the awkwardness of the original language while still retaining some commitment to correct syntax. The ungainly writing style of the army documents appears connected not just to the educational level of the officers, but also to the confusion of their own thinking when trying to reconcile the official propaganda line with the reality they faced. 
fool them by overt expressions of loyalty: "Are there still many people who are twofaced?"24

Despite the army's stated confidence in the loyalty of the East Timorese, its practice was to regard all of them with distrust. A book of cartoons issued by the Intelligence Taskforce (Satuan Tugas Intelijen, abbreviated SGI) reveals the occupying force's sense of alienation from the subject population. The army in East Timor apparently believed the soldiers had to be instructed like grade-school children in lessons that should have been taken for granted; the cartoons showed that sexually harassing women, beating up civilians, and stealing property were wrong. Several of the cartoons, such as Figures 1 and 2 reproduced below, taught the soldiers that ordinary East Timorese, even those working for them, were indeed "two-faced" and should be suspected as informants for the resistance. ${ }^{25}$

If the reports in the HAK Collection are representative, the military never reassessed its consistent inability to destroy the resistance. When the military invaded in 1975, its leading generals predicted the resistance would be finished off in three weeks. ${ }^{26}$ Every few years afterward, the military announced another major offensive that was certain to eliminate the guerrillas once and for all. Each offensive, designed like all counterinsurgency warfare to inflict great suffering and death upon civilians, did indeed weaken the guerrillas. Yet each time, Falintil managed to reemerge Phoenixlike from the ashes. The army never came to the obvious conclusion that many people, not just a small devious clique of civilian members of a clandestine front, were strongly determined to feed, shelter, and provide information to Falintil and continually replenish its ranks.

\section{Fighting the Civilian Resistance}

In opening East Timor to foreigners in 1989, the Suharto regime wished to prove to the world that the resistance had been defeated and that East Timor had become a normal province of Indonesia. To handle the resistance within this new context, the military command structure for East Timor was reorganized in 1989 and renamed Kolakops. The basic structure of Kolakops, as diagrammed in a secret document reproduced below (see Figure 3), was Cycloptic: all military units in East Timor, whether navy, air force, intelligence, police, or army, were under the command of one army brigadier general. The Kolakops commander worked under the commander of Indonesia's $9^{\text {th }}$ Military Area (Kodam IX) covering the eastern chain of islands from Bali to East Timor. ${ }^{27}$

24 Kodam IX Kolakops, Rencana Operasi "Halo Kapaz," appendix C, p. 16; Kodam IX Kolakops, Perintah Operasi "Tuntas $I$," appendix C, p. 14.

25 Korem 164, Satuan Tugas Intelijen, Petunjuk Intelijen Pengamanan Praktis (Dili, no date; Secret).

26 Ben Anderson, "Gravel in Jakarta's Shoes," in his The Spectre of Comparisons: Nationalism, Southeast Asia and the World (London: Verso, 1998), p. 133.

27 Kodam IX Kolakops, Rencana Operasi "Halo Kapaz." The overall command structure began in 1976 as Kohankam and then transmuted into Koopskam in 1984. Kohankam stood for Defense Security Command (Komando Pertahanan Keamanan). Koopskam stood for Security Operations Command (Komando Operasi Keamanan). On the history of this structure, see "The Kopassus-Militia Alliance," Tapol Bulletin 154/55 (November 1999). 

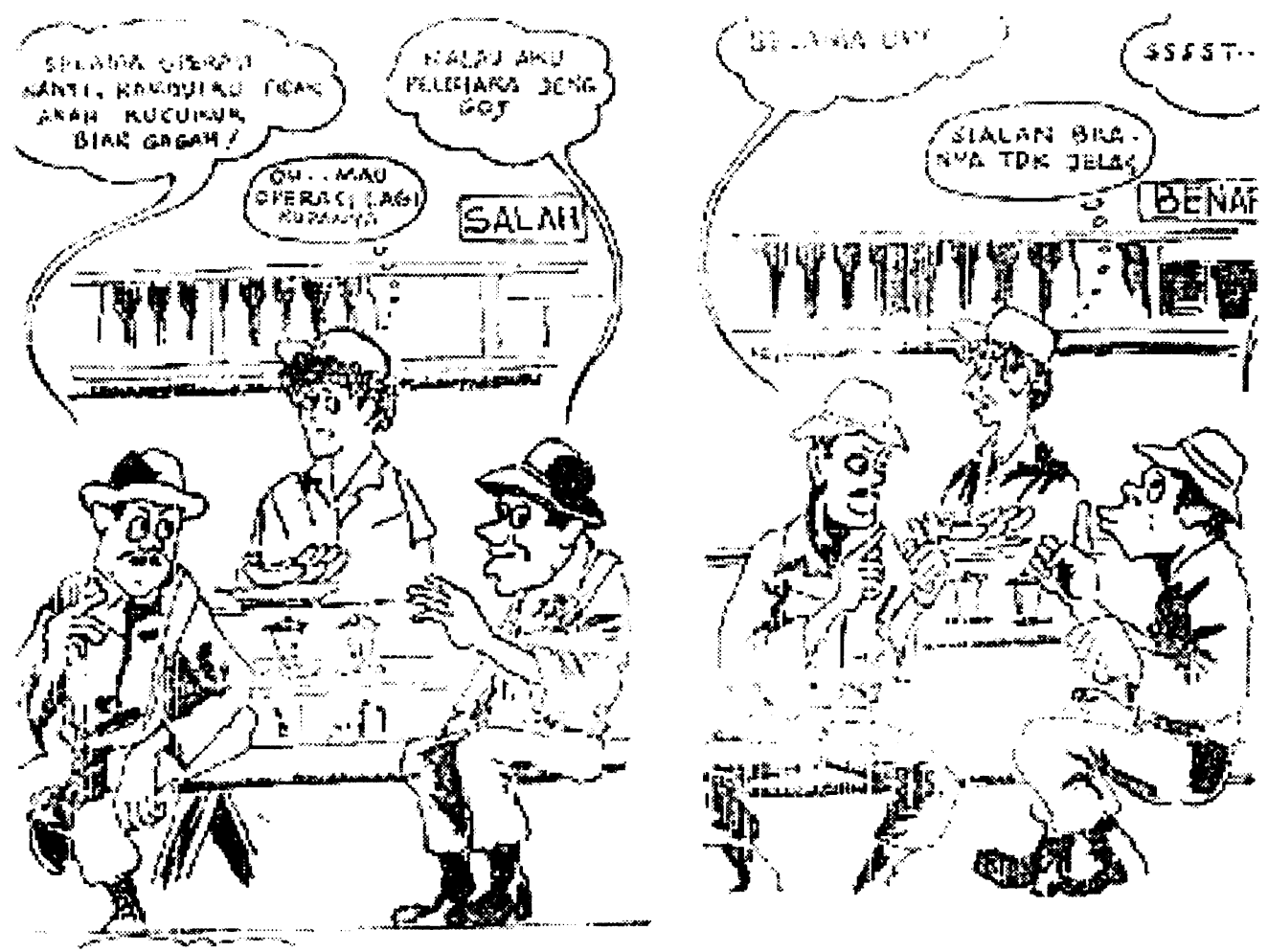

Left Scene: WRONG

First Soldier: During the upcoming operation I'm not going to cut my hair so that I'll look macho.

Second Soldier: As for me, I'm going to grow a beard.

Food Stall Owner: Oh - it seems like there'll be another operation.

Right Scene: CORRECT

First Soldier: During the op ...

Second Soldier: Shhhh...

Food Stall Owner: Damn. It's not clear what they're saying.

Figure 1 


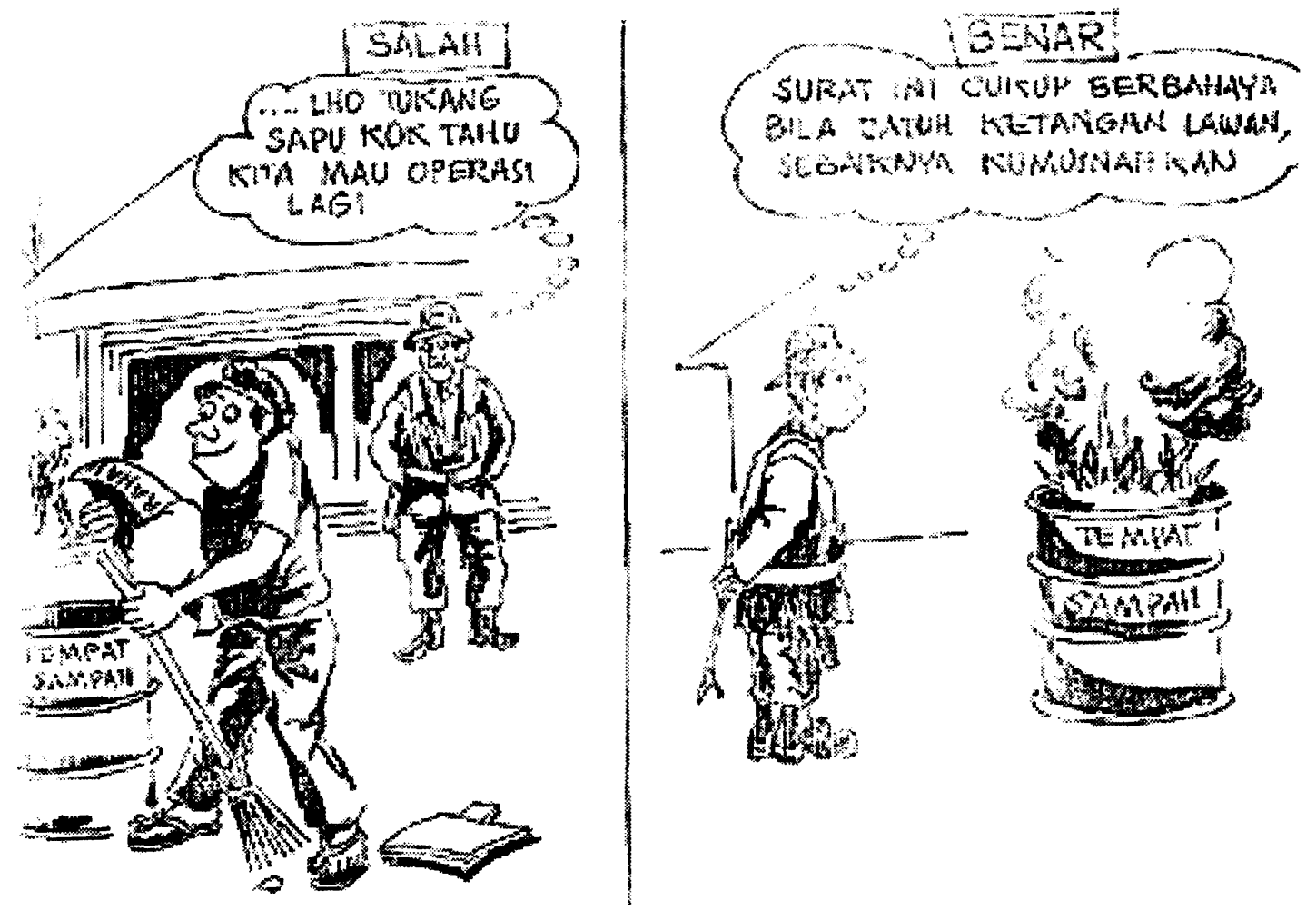

Left Scene: WRONG

The sweeper holds a document marked 'secret' above the trash bin.

Soldier: How come the sweeper knows that we're going to have another operation?

\section{Right Scene: CORRECT}

Soldier: These documents are dangerous if they fall into the enemy's hands. It's better if I destroy them.

\section{Figure 2}


The army had two types of troops in East Timor: those stationed for long-term stays and those brought in on annual rotations. The former were called organic (organik) or territorial troops. They were stationed within the territorial structure, which consisted of one Korem covering all of East Timor, thirteen district-level Kodims, and sixty-two sub-district level Koramils. At the lowest rung of this hierarchy were 464 village-level soldiers (babinsa). The latter type of troops were called nonorganic (non-organik) or assigned (penugasan) troops. They were infantry battalions whose home bases were outside East Timor, such as in the Kodams in Java, Sumatra, and Sulawesi. These battalions, once brought to East Timor, were each stationed in one of three sectors delineated for "non-organic" troops. East Timor had been since the first years of the occupation divided into three sectors: Sector A covered the eastern half and was headquartered in Baucau; Sector B covered the western half and was headquartered in Ainaro; Sector $C$ covered the district of Dili. In the army's perspective, the non-organic troops were necessitated by the existence of armed resistance; if there was no combat, these troops would have been withdrawn and the sectoral structure disbanded. The territorial troops, however, would have been kept in East Timor whether or not there was combat. They were a standard part of the army's nation-wide territorial structure.

The coordination between these two different types of troops was fairly clear-cut during the duration of Kolakops from 1989 to 1993 . The Kolakops commander was in charge of both. Directly underneath him stood the three commanders of the sectors. According to the 1989 diagram of Kolakops, the territorial structure was not an autonomous chain of command; it was entirely subsumed under the sectoral structure. Sectors A, B, and C appeared on the diagram. (Sector C was shown as the "special sector," sektor khusus.) The highest level of the territorial structure in East Timor, the Korem, did not appear at all. A similar diagram of the Kolakops hierarchy included within the April 1992 report on Operasi Tuntas also placed the territorial structure underneath the sectors. ${ }^{28}$ The lower levels of the territorial structure (the Kodims and Koramils) were included within Territorial Taskforces (Satuan Tugas Teritorial), which were under the command of the sectors. Detailed listings of the components of the Territorial Taskforces (not reproduced here) reveal that they were a combination of the territorial troops and the non-organic troops. Within each Territorial Taskforce was a Kodim, a detachment of a non-organic infantry battalion, and a civil militia (wanra). ${ }^{29}$ If the diagrams of 1989 and 1992 are indeed accurate reflections of the chain of command, the most powerful officers, apart from the Kolakops commander himself, were the commanders of the three sectors.

${ }^{28}$ Kodam IX Kolakops, Perintah Operasi "Tuntas-I," appendix A, sub-appendix I.

29 Kodam IX Kolakops, Rencana Operasi "Halo Kapaz," appendix B, "Susunan Tugas." 

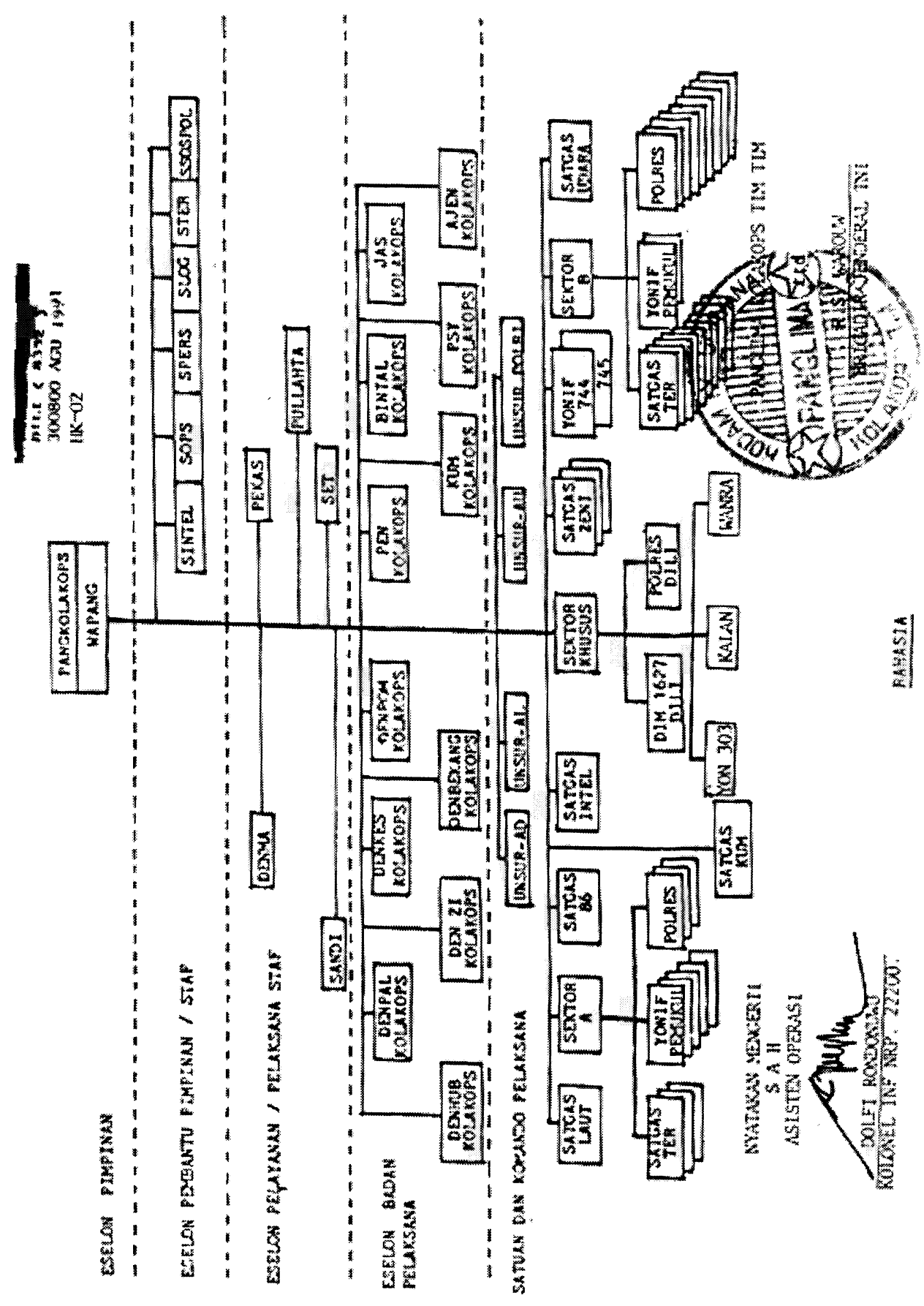

The Indonesian Army Command Structure for East Timor in 1991

Source: Kodam IX Kolakops, Rencana Operasi 'Halo Kapaz,' (31 August 1991; Secret).

Figure 3 

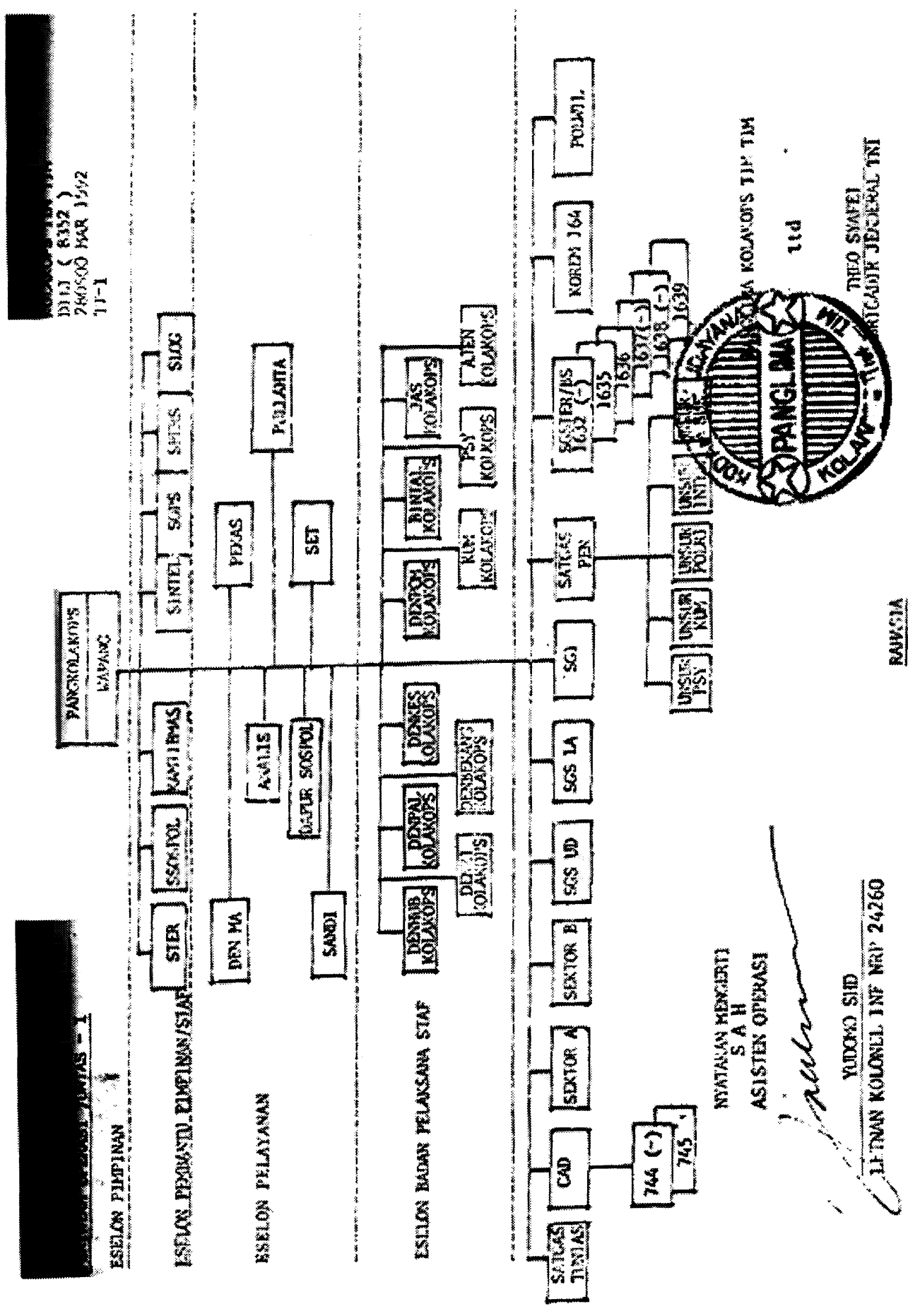

The Indonesian Army Command Structure for East Timor in 1992

Source: Kodam IX Kolakops, Perintah Operasi 'Tuntas I' (April 1992; Secret).

Figure 4 
Under Kolakops, the territorial and non-organic troops were intermixed. Territorial troops were routinely recruited for combat operations and non-organic troops were involved in policing duties. Non-organic troops were divided into two types: those assigned to the Territorial Taskforces and those assigned to combat duty. Many of the non-organic troops assigned to the Territorial Taskforces were in what was called Batalyon Teritorial, or BTT. These soldiers were usually young Javanese privates in their late teens and early twenties on one-year tours of duty. Their assignment was to live among the people, get to know them, befriend them, and help them in their daily lives. This "winning hearts and minds" strategy was designed to instill Indonesian patriotism in the people, gain intelligence information about resistance activities, and determine the identity of the clandestine supporters of the resistance. This network of BTT posts was one of the most conspicuous signs that East Timor was under a military occupation. Within Dili, there were fifty-seven BTT posts with an average of ten soldiers per post. ${ }^{30}$ The BTT soldiers were not quartering in barracks-they were living in the house next door.

With the "normalization" of East Timor in 1989, one would have expected the army to de-emphasize the sectoral structure, which was primarily designed for combat operations, and elevate the status of the territorial structure. But the army, even three years after the "normalization," appears to have continued to view East Timor as a region of combat and did not choose to compromise the predominance of the sectoral commanders. ${ }^{31}$

One of the regime's first major tests of the new "open door" policy一the scheduled visit of a Portuguese parliamentary delegation-put the army on high alert. It drafted a 150-page planning document complete with a detailed three-month schedule for the preparations prior to the visit, which was scheduled for November 1991. The army brought in three additional Strike Force units (1,629 soldiers) and appointed ten thousand soldiers to guard the routes of the delegation. It carefully planned what the delegation would see and whom it would meet. Apart from buying thirty thousand Indonesian flags to be flown from nearly every house and building, the army budgeted millions of rupiah for development projects, such as well repair. ${ }^{32}$ The Kolakops commander, Brig. Gen. Warouw, ordered the troops to spiff up development projects and to "direct the people who have been pre-selected to receive the delegation with activities supporting integration." It distributed rice, money, and jackets to one thousand East Timorese militia members in Dili and organized them to stage demonstrations in favor of integration. Meanwhile, the troops were to "prevent the public from supporting the anti-integration group to stage demonstrations" and to "prevent the delegation from communicating with the anti-integration group, especially

\footnotetext{
${ }^{30}$ For a complete listing of the posts in Dili, see Polda Dili, Prosedur Tetap Tentang Pedoman Penanggulangan Huru Hara Kota Dili (Dili, November 1, 1997; Secret), pp. 12-14.

31 Douglas Kammen has argued that the shift in emphasis from the combat to the territorial command began in 1989 with the opening up of East Timor. This does not appear to have been the case since, as seen in Figure 3, the entire territorial command does not appear in the Kolakops hierarchy two years after the opening. The documents only indicate such a shift in the aftermath of the 1991 Santa Cruz massacre. Douglas Kammen, "Notes on the Transformation of the East Timor Military Command and Its Implications for Indonesia," Indonesia 67 (April 1999), p. 65.

32 Kodam IX Kolakops, Rencana Operasi "Halo Kapaz," appendix H.
} 
at the schools. ${ }^{\prime 33}$ From these preparations, it is obvious the army was not relying on the East Timorese to express their support for integration voluntarily.

Thinking the delegation's visit would improve Indonesia's international image, the military named the operation "Halo Kapaz," a Tetun phrase meaning "to make better." The end result was, however, the opposite of what had been planned: the delegation refused to come when one member was denied a visa and the underground East Timorese resistance used the opportunity of a funeral procession on November 12 to stage a demonstration. Thousands of East Timorese, in an unprecedented display of support for independence, marched through the streets of the capital city to the Santa Cruz cemetery. Some broke into a run, exhilarated by such a rare chance to openly express their desire for independence. The Indonesian army could not restrain itself from resorting to the methods of counterinsurgency warfare that it had long practiced in East Timor. ${ }^{34}$ The massacre of about three hundred unarmed men, women, and children in front of the entrance to the cemetery, witnessed and videotaped by foreign journalists, prompted the most serious international crisis for Indonesia since the 1975 invasion.

The HAK Collection does not contain documents revealing the army's decisionmaking process in the wake of the Santa Cruz massacre, but the process can be inferred from the actions the army took. The lesson that the army appears to have learned from the massacre was that its force structure was unsuitable for dealing with the clandestine civilian resistance. In the two years after the massacre, it undertook three types of reforms. First, it reduced the number of non-organic troops and increased the number of territorial troops. Secondly, it partly removed the territorial structure out from under the sectoral structure. Thirdly, it transferred control of the non-organic troops from Kostrad (the Army Strategic Command) to the covert operations and psychological warfare experts of the army's special forces, Kopassus. Let us consider each of these three changes in more detail.

The shift in the balance of non-organic and territorial troops can be seen from the table below. In the six year period after the massacre, the ratio of non-organic to territorial troops went from $2: 1$ to $2: 2.5$. In reducing the number of non-organic troops and simultaneously increasing the number of territorial troops, the army hoped to create an occupation force that was more closely integrated with the population. The territorial troops, stationed in East Timor for long-term stays, some indefinitely, were supposed to develop better relations with the population than those troops rotated in and out on short-term tours.

\footnotetext{
33 Kodam IX Kolakops, Rencana Operasi "Halo Kapaz," appendix E, p. 12.

34 The editors of Indonesia and Douglas Kammen have argued that the Santa Cruz massacre was the work of a group of officers who wished to discredit the Kolakops commander Warouw. Editors, "Current Data on the Indonesian Military Elite, July 1, 1989-January 1, 1992" Indonesia 53 (1992): 93-136; Kammen, "Notes on the Transformation." This argument is based on speculation. One could, if wishing to speculate, generate many other equally valid scenarios. Lacking any firm information, I think it is best to describe the massacre as what it most certainly was: a massacre committed by an army that had been regularly massacring East Timorese since 1975.
} 
Table 2

Number of Troops in East Timor 1991-1998

\begin{tabular}{|l|c|c|c|c|}
\hline \multicolumn{1}{|c|}{ Date } & $\begin{array}{c}\text { Non-organic } \\
\text { Troops }\end{array}$ & $\begin{array}{c}\text { Territorial } \\
\text { Troops }^{\text {a }}\end{array}$ & Civil Militias $^{\mathbf{b}}$ & Totalc $^{\mathbf{c}}$ \\
\hline August 1991 & 11,000 & 4,792 & 2,475 & 20,736 \\
\hline April 1992 & 8,444 & 5,169 & 1,338 & 19,696 \\
\hline November 1997 & 6,172 & 9,740 & 2,129 & 19,633 \\
\hline July 1998 & 7,938 & 9,896 & 2,129 & 21,540 \\
\hline August 1998 & 7,938 & 9,976 & 2,129 & 21,620 \\
\hline
\end{tabular}

Sources: Kolakops, Rencana Operasi “Halo Kapaz" (August 1991), appendix H, p. 7. Kolakops' Perintah Operasi "Tuntas I" (April 1992), appendix G, p. 7; Leaked Korem personnel section documents, 1997-98. Notes:

a The territorial troops include policemen.

$\mathrm{b}$ The army and police had a variety of civil militia: Wanra, Kamra, Ratih, and Hansip.

${ }^{c}$ The total includes personnel from the navy, air force, and miscellaneous other units.

Though the composition of the troops changed from 1992 to 1997 , the overall number of troops remained the same. The East Timorese continued to live under one of the most intensive military occupations of modern history. The ratio of military personnel to civilians remained constant at about one to thirty-eight (taking the population of East Timor as 815,000 persons, of whom perhaps fifty thousand were Indonesians). The military maintained a ubiquitous presence among the civilian population even after most of the counterinsurgency warfare had ended. Resident in every village and neighborhood was at least one soldier (a babinsa), one policeman (a binpolda), and one platoon of about ten to twelve soldiers of the BTT.

The second change in military policy instituted after the Santa Cruz massacre was the partial separation of the territorial structure from the sectoral structure. We have few documents for the period 1993-95 that show exactly how this separation was effected, but we have many more for the period 1995-99 clearly indicating that it had taken place. Instead of being combined under a single Kolakops commander, the territorial and sectoral structures were partly separate by this time and thus devised their own yearly plans. The year 1995 marked a turning point. It was in that year that a new master plan for the territorial structure, Operation Tatoli I, was introduced. The plan was renewed every year, perhaps with some small updatings and revisions, for the next four years. Thus, there were Operations Tatoli I, II, III, and IV for the period 1995 to 1998. Likewise, a new master plan named Rajawali (Hawk) was introduced for the non-organic troops of the sectoral structure in 1995. The first year of this new operation was Rajawali I, and subsequent years were Rajawali II, III, and IV. The infantry battalions of the sectors were officially designated Rajawali troops and wore patches on their uniforms marking them as such. Unfortunately, we do not have any diagrams of the overall structure of the army in East Timor after Kolakops was ended in 1993. How the territorial and non-organic troops were coordinated in the absence of an overall commander is not entirely clear. As before, the two types of troops were combined for both combat operations and policing duties. It may be that the Korem 
commander gained authority, becoming more nearly equal to the sector commanders, and that they jointly determined the day-to-day operations of the occupation force.

The third change was the increasingly more powerful role of the army's special forces, Kopassus, within the sectoral structure. Around the time of the Santa Cruz massacre, the sectors had been dominated by Kostrad. In 1992-93, the commanders for Sectors A and B were Lt. Col. Kirbiantoro and Lt. Col. Djamari Chaniago (respectively), both of whom simultaneously commanded Kostrad troops. The commander of Sector $C$ at the time was Col. Moch. Thamrin, who simultaneously commanded a Kostrad infantry brigade (Brigif Linud 3) ${ }^{35}$ The infantry battalion placed in Dili, the most sensitive district, in preparation for the arrival of the Portuguese parliamentary delegation in November 1991, was from Kostrad (Yonif 303). Another Kostrad battalion was posted to nearby Ermera district (Yonif 411). ${ }^{36}$ Kostrad was clearly the dominant force. Yet, by the mid-1990s, there does not appear to have been a single Kostrad battalion in East Timor.

The decline of Kostrad meant the rise of Kopassus. According to a listing of Rajawali III troops in 1997, the highest-ranking officer in the sectoral structure was from Kodam IX: Col. Djody Kusuma, the commander for Sector A. But most of the key officers directly under him were from Kopassus: the commander of Sector B and the deputy commander of Sector A were Lieutenant Colonels from Kopassus. The head of the intelligence department for Sector A was a Captain from Kopassus. ${ }^{37}$ In 1998-99, all the commanders and vice-commanders for Rajawali IV sectors A and B were Kopassus officers. ${ }^{38}$ Although the number of Kopassus troops in East Timor was relatively small, the position of a select group of Kopassus officers was very powerful; they were put in command of the five non-organic infantry battalions. ${ }^{39}$

Since, as noted above, the documents do not clarify the coordination between the territorial commanders and the sectoral commanders, it is difficult to determine the extent to which Kopassus was able to extend its power into the territorial structure and control the occupation forces as a whole. The territorial structure is likely to have

\footnotetext{
35 Kammen, "Notes on the Transformation," pp. 70-71.

36 Kodam IX Kolakops, Rencana Operasi "Halo Kapaz," appendix D.

37 Korem 164, Satgas Darat III, Daftar Nominatif Personil Satgas Darat Rajawali-III/1997 Yang Diusulkan utk Mendapatkan Setya Lencana Seroja (Dili, September 1997; Confidential). This document lists 1,456 names of officers and soldiers recommended for a certain type of medal (a medal named after the army operation to invade East Timor on December 7, 1975, Operasi Seroja-Operation Blooming Lotus). Lt. Col. Geerhan Lantara, an officer with a Kopassus background, was commander of Sector B in early 1996. (Komandan Sektor B, Surat Telegram kepada Komandan Korem 164, March 30, 1996.) Lantara had extensive experience in East Timor dating back to the late 1970s. During the Santa Cruz demonstration in 1991, Lantara was knifed and had to be evacuated for medical treatment. See, Tapol Bulletin 108 (December 1991). He was in East Timor in September 1999 during the scorched earth operation according to an Indonesian journalist accompanying the military (personal communication).

38 The commander of Sector A was Col. Sunarko; the commander of Sector B was Lt. Col. Tatang Zaenudin; the vice-commander of Sector A was Lt. Col. Sunindyo; and the vice-commander of Sector B was Lt. Col. Nus. All four were from Kopassus. I am grateful to a member of Yayasan HAK who compiled a complete table of the officers serving in East Timor in 1998-99 based on a thorough reading of the documents of the HAK Collection.

39 The leaked Korem personnel documents reveal that there were 503 Kopassus commandos in East Timor in 1998. The Kopassus contingent was named the Satuan Tugas Tribuana (Three Worlds Taskforce).
} 
been liberally laced with Kopassus officers, especially when Suharto's son-in-law, Prabowo, was Kopassus commander (1995-98) and able to exercise great influence within ABRI. Kopassus may have served as the overall coordinator of army operations in East Timor in the mid to late 1990s. What we see in the documents is the formal structure and not the play of personalities and inter-service rivalries behind it. There are many gaps in our knowledge of how the chain of command functioned in practice.

Kopassus had been in East Timor from the start of the occupation. When it was named Kopassandha, it had participated in the invasion of December 1975. Reports from East Timorese during the 1980s often mentioned the involvement of Kopassus troops and officers in the counterinsurgency warfare and human rights violations. The post-1993 reorganization transformed Kopassus from just one component of the occupation forces into a central pillar. At the time of the vote in August 1999, nearly all of the military's key officers related to East Timor had previously served as Kopassus officers. Such officers included the commander of Kodam IX, Maj. Gen. Adam R. Damiri; his Chief of Staff, Brig. Gen. Mahidin Simbolon; the commander of Korem 164, Col. Tono Suratman; his replacement in late August, Col. Noer Muis; the head of the government's task force on the vote, Maj. Gen. Zacky Anwar Makarim; the martial law administrator dispatched in early September, Maj. Gen. Kiki Syahnakri; and Maj. Gen. Sjafrie Sjamsoeddin, an assistant to Gen. Wiranto, who was dispatched to East Timor immediately before and after the vote. ${ }^{40}$

Kopassus is the branch of the army that specializes in covert action and psychological warfare. The army high command, searching for new methods to defeat the resistance, transferred authority over the non-organic troops to Kopassus in the mid-1990s precisely because of this specialization. The HAK Collection happens to contain a manual for Sandi Yudha, the covert operations unit of Kopassus. The manual, dated June 1999, originated from army headquarters in Jakarta. It describes the chain of command and the division of responsibility within Kopassus. One page lists the topics in which the soldiers of the Sandi Yudha unit were educated at Kopassus's training center in Batujajar, near Bandung in West Java. These topics

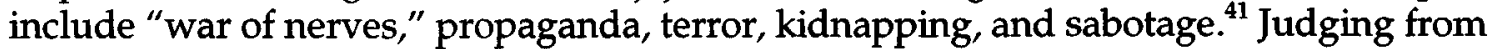
other army intelligence documents, it is clear that Kopassus training focuses on how to carry out such acts, not to prevent them. Covert action or, in the army's own euphemism, "mobilization" (penggalangan), is presented in one official manual as a function of the Army's intelligence-not as an enemy action that must be guarded against and prevented. The "object of mobilization" is defined as a person or organization that presents a threat or the potential to become a threat to security and stability. The objects can be "inside or outside the country." Mobilization, the manual advises, "must be planned" and its practitioners must "consistently hold fast to secrecy" and "be flexible according to the conditions faced without changing the goals of the mobilization." These are prescriptions and guidelines for conducting covert operations. $^{42}$

40 "Sjafrie denies role in attack on Belo's residence," Jakarta Post, December 30, 1999.

41 TNI Markas Besar Angkatan Darat, Buku Petunjuk Pembinaan tentang Sandi Yudha TNI-AD (June 30, 1999, Confidential), p. 35.

42 ABRI Markas Besar TNI-AD, Buku Petunjuk Induk tentang Intelijen TNI-AD (1998, Secret), pp. 10-11. 
Two of the three post-Santa Cruz massacre changes described above-the increase in the number of territorial troops and the partial autonomy given to the territorial structure--were designed to anchor the army more firmly within the East Timorese population. But they were not accompanied by a "Timorization" of the troops. The army of occupation remained entirely under the direction of non-East Timorese. The Korem, all thirteen Kodims, and all sixty-two Koramils were commanded by Indonesians. From a listing of the 211 top positions in the territorial staff in 1998, one cannot identify a single Portuguese- or East Timorese-sounding name. ${ }^{43}$ The officers of the sectoral command were all non-East Timorese, as were all of the non-organic troops. The military had managed to recruit a fairly large number of East Timorese into the army and police; by the late 1990s, the number reached about 30 percent of total personnel. But all of these East Timorese were at the lowest ranks: 90 percent of them were corporals and privates, and majority of these were not full-time soldiers. Most East Timorese soldiers were recruited under the program called Milsas, short for Militerisasi, or Militarization, which gave them three months training and then kept them on reserve. Fifty three percent of all East Timorese privates were in Milsas. To a greater extent than many colonial powers in history, the Indonesian army did not cultivate a group of "native" army officers. The army did not, or could not, trust the East Timorese to lead the war on the resistance and relied almost entirely on Indonesian troops to guarantee the territory's continued integration with Indonesia.

\section{Mobilizing the Militias}

In the wake of the Santa Cruz massacre, army intelligence realized that its existing network of East Timorese informants and toughs had failed miserably in preventing such a large-scale demonstration from occurring in the first place. Writing in 1992, Lt. Col. P. Napitupulu, the head of the Intelligence Team, noted that the army already had local collaborators, "Wanra, Hansip and special Teams designed to help destroy Fretilin's strength." ${ }^{\prime 4}$ But he felt the need for something new and better. He diplomatically noted that he did not want to slight the non-organic troops as incompetents who "could not adequately carry out their duties." He merely wanted to suggest that the army would benefit by drawing more upon the work of Kopassus, which had long been using ex-Falintil soldiers to hunt down their erstwhile comrades. Kopassus (in its former incarnation as Kopassandha) had organized the first such unit, the Nanggala Unit, most of whose members were "ex-Fretilin or ex-GPK who had been captured and brought down [from the hills] and used in their respective regions since they knew the regional situation and the combat tactics of the enemy." The paradigm he suggested the army follow throughout East Timor was that pioneered in

43 The statistics in this paragraph are based on personnel documents leaked in 1998 by an East Timorese man working in the Korem office. For a description of the background and content of these documents, see Comissão para os Direitos do Povo Maubere (Lisbon), "Military Intelligence Services (SGI) and the Indonesian Armed Forces (ABRI) in East Timor," (April 1999).

44 Lt. Col. P. Napitupulu, Kepala Tim Analis Intelijen (Dili), "Memo Intelijen" nomor R/43/MI/IV/1992, kepada Komandan Kopassus, April 21, 1992. 
the eastern sector, Sector A, where three East Timorese militias (Team Sera, Team Alpa, and Team Makikit) were operating under the command of Kopassus. ${ }^{45}$

Kopassus, having been handed control of the non-organic troops by the mid-1990s and given the assignment of wrecking the clandestine civilian resistance, drew upon its experience of organizing East Timorese militias. It established a new militia named Youth Guards for Integration, or Gada Paksi (Garda Muda Penegak Integrasi). The novelty of Gada Paksi lay in its combination of employment schemes with intelligence gathering and in the close attention that high officers of Kopassus lavished upon it. As noted above, the army believed that the clandestine resistance consisted of confused, volatile youth frustrated with the lack of employment prospects. Kopassus designed Gada Paksi to function overtly as an employment agency, providing job training and paid work in various small-scale industries and shops. The ulterior purpose was to create another pool of spies and musclemen who could be called upon to identify and terrorize members of the clandestine resistance. Some of the militia leaders who came to prominence in 1999, such as Eurico Guterres and Manuel de Sousa, were former leaders of Gada Paksi. Guterres, a youth in his twenties, was given a particularly lucrative job: control over a gambling racket in Dili.

The HAK Collection is particularly rich in documents pertaining to Gada Paksi. The training of Gada Paksi began under the authority of a letter from the commander of Kopassus, then Brig. Gen. Prabowo, on July 4, 1995. The point man in East Timor for the training was the head of the Korem's Intelligence Operations department, Capt. Handy Geniardi. In this case, Kopassus was working through the territorial structure. Capt. Geniardi wrote regular reports about Gada Paksi members, finances, and activities. He mentioned in one report that the Kopassus commander had established Gada Paksi with a grant of Rp. 400 million in 1995 (about \$200,000 at the 1995 exchange rate). Within a year, Capt. Geniardi was looking after the employment of four hundred youths working in places such as repair shops, slaughterhouses, stone and wood selling businesses, and furniture workshops. ${ }^{46}$ The intelligence department of the Korem continued the funding for the year 1996-97, and the Kodims from all over East Timor drew up the lists of recommended new recruits. ${ }^{47}$ The army organized a Gada Paksi chapter in Surabaya among the East Timorese community there. When Capt. Geniardi went to Surabaya to check up on the chapter in November 1995, he instructed the members to spy on other East Timorese and report to the intelligence officers of Kodam V in east Java. ${ }^{48}$

The future of Gada Paksi did not appear bright once Suharto fell from power in May 1998. The army of occupation was uncertain of its mission and its guarantees of impunity. Suharto's son-in-law, Maj. Gen. Prabowo, Gada Paksi's godfather, was dismissed from the army in late August 1998 for directing a Kopassus operation in

\footnotetext{
45 Ibid.

46 Fax from Capt. Handy Geniardi to Major Agus, "Laporan Mingguan" (Dili, February 24, 1996). Korem 164, Satuan Tugas Melati, "Daftar Anggota Gada Paksi Yang Berkerja" (not dated, c. 1996).

47 Korem 164, "Daftar Personil Calon Pelatihan Gada Paksi Angkatan Ke-III Tahun 1996-97" (May 1996); Kodim 1628, "Bahan Rapat Koordinasi Penentuan Calon Gada Paksi Gel-III Tahun 1996-1997" (Baucau, April 1996; Limited).

48 Capt. Handy Geniardi, "Laporan Bulanan Kegiatan Pelatihan Gada Paksi di BLK Surabaya," (November 10, 1995).
} 
Jakarta to kidnap and torture Indonesian activists. Once it became clear that Prabowo was on the way out, East Timor's daily newspaper, Suara Timor Timur, felt bold enough to demand the disbandment of Gada Paksi. The newspaper represented the opinion of loyal civilian collaborators disturbed by the lawlessness of Kopassus's youth gangs. The head of Gada Paksi, Marcal de Almeida, stated that he was willing to see it disbanded as long as the jobs of the members were guaranteed. He admitted to receiving Rp. 400 million from Prabowo in 1995 and lamented that the money had run out. ${ }^{49}$ Gada Paksi faded away in late 1998 as its leaders squabbled with one another in the struggle to secure new funding and its members joined the new militias being formed by the army to attack the unprecedented upsurge of open resistance to the occupation.

\section{Responding to the Resistance after Suharto's Fall}

The army viewed the explosion of pro-independence demonstrations in the months immediately after Suharto's fall with great alarm. It remained convinced that the majority of the East Timorese were loyal to Indonesia and thus attributed the fact that tens of thousands of people joined the demonstrations to the gullibility of the East Timorese public who had been manipulated by the pro-independence clique during an economic and political crisis. The students in the forefront of one demonstration were, as an officer in Dili reported, merely "naughty children" (anak nakal), malcontents venting their frustrations. ${ }^{50}$ The East Timorese, the army believed, could easily revert to their former pro-Indonesian sympathies if they were shown that the army remained firmly in control and that many of their fellow East Timorese were solidly behind the army.

To turn the pro-independence tide in mid to late-1998, the army once again deployed the militia strategy. It reinvigorated its old militias and created new ones. The great virtue of the militia strategy was that it allowed the army to terrorize the pro-independence supporters without the army itself appearing as the perpetrator. In 1998, it was especially important that the army be able, plausibly, to deny its involvement in actions of this sort because at the time the new Habibie government felt acutely conscious of being in the international spotlight and vulnerable to the human rights concerns of the countries providing the money to salvage the country's economy. The army drew upon its long experience in mobilizing civilian militias to blur the issue of responsibility. Army intelligence in East Timor, though deluded in its perception of its enemy, considered itself the master of illusion, fully capable of deluding others.

The army became determined to launch a large-scale terror campaign against the East Timorese resistance in late 1998, when it found itself confronted by not only ongoing, non-violent civilian resistance, but also a dramatic insurgent strike against an

49 "Gada Paksi Boleh Bubar?," Suara Timor Timur, August 14, 1998. For Marcal de Almeida's statements, see "Gadapaksi Boleh Bubar, Asal Dijamin," Suara Timor Timur, August 13, 1998. The editor of the newspaper, Salvador Soares, was a leader of the unarmed non-militia side of the pro-integration campaign in 1999.

${ }^{50}$ Lt. K. T. Kompiang, Commander of intelligence section of Kodim 1627, "Nama-nama Anak Nakal dan Tokoh2 yg terlibat kasus mimbar bebas dan unjuk rasa," not dated, c. October 1998. 
army position. Falintil guerrillas conducted a successful raid on a sub-district military headquarters, a Koramil, in the town of Alas (Manufahi district) on November 9. Three soldiers were killed in the attack (perhaps by the local civilians and not by the guerrillas), thirteen soldiers were captured (and most released soon afterward), and a valuable stockpile of weapons was taken. ${ }^{51}$ This upsurge of both non-violent protests and armed actions portended serious problems for the sustainability of the occupation. Moreover, a prominent demand at all the demonstrations of 1998 was the disbandment of the army's East Timorese militias.

The army's expanded militia strategy began to take effect in mid-December when a new militia, Mahidi, was established for Ainaro district. Led by a young local notable employed as a civil servant, Cancio Lopes de Carvalho, Mahidi held its formal inauguration on January 1, 1999 with the Kodim commander, district police chief, and several district legislators as honored guests. Cancio, proud of his newly elevated status, bragged to a $\mathrm{BBC}$ reporter that the army had given his group automatic weapons. ${ }^{52}$ The army's investment quickly paid off. Within the first week of January, Mahidi's guns killed two civilians and wounded ten more. As militiamen conducted sweeps through the villages to forcibly recruit young males and intimidate supporters of independence, hundreds of terrified people fled from Ainaro district. Mahidi extended its reach to Suai district and similarly generated a massive refugee crisis there. Some six thousand villagers had taken shelter in the Suai church compound by the end of January. As part of their reign of terror, militiamen shot and killed ten civilians, including a pregnant woman and a teenage boy, in the village of Galitas in Suai in two incidents on January 24 and 26. In these cases, as in all subsequent ones, the army and the militia falsely claimed that there had been shootouts with armed members of the pro-independence side. The army created a similar scenario in Liquisa with the Besi Merah Putih (Red and White Iron) militia, which had been established on December 27, 1998. Terrified by the Besi Merah Putih, thousands of villagers fled their homes in the early months of 1999 and sought shelter either in the Liquisa church or in remote campsites in the valleys of the interior hills. The army also terrorized Bobonaro district with the Halilintar (Lightning) militia, headed by its longtime collaborator, João Tavares. Thus began the army's killing spree by proxy and its construction of the simulacrum of civil war.

These militias were operating under the command of the sectoral structure, meaning Kopassus. The Commander of Sector A looked after the militias of the eastern districts. He wrote a letter to the Health Department of Baucau in early 1999 to request medicine for six hundred militiamen of Sera, Alfa, and Saka. The aid was meant "to raise the morale of the members and sympathizers" of the militias. ${ }^{53}$ According to the leaked Korem personnel documents of 1998, the various militias, such as Tim Sera, Alfa, and Saka, were attached to the Kopassus contingent in East Timor, Satuan Tugas Tribuana. The militias were organized by district, with each of the thirteen districts having at least one militia, but they were grouped into two sectors:

\footnotetext{
51 East Timor Human Rights Centre, UA 17/98, November 23, 1998; Yayasan HAK, testimony of two female victims of torture from Alas, December 1, 1998.

52 Jonathan Head, BBC radio report, February 5, 1999.

${ }^{53}$ Komandan Satuan Lapangan-A, "Permohonon Dukungan Obat Bulanan Pos dan Kes Satlap-A" (Baucau, March 1999).
} 
Sectors A and B. The letterhead of Aitarak, the militia for Dili district, read: "Aitarak Forces Command Headquarters Sector B" (emphasis added). As if to remind East Timorese of the identity of his powerful backer, Eurico Guterres, the head of Aitarak, consistently wore a Kopassus baseball cap, distinguished by the emblem of a slender upright silver sword.

In organizing, arming, funding, and directing the militias, Kopassus and the nonorganic troops under its command did not act alone. The Korem and Kodim commanders worked closely with the militia leaders and provided logistical support. From reports by human rights investigators, it is clear that territorial troops were involved in nearly all of the large-scale killings committed by the militias from January to September 1999. The Kodim of Liquisa district served as a coordinating center for the militias when they massacred unarmed civilians in a church in April. The Kodim commander of Suai, Lt. Sugito, directed the assault on the refugees and priests at the Suai church in September. ${ }^{54}$ Although Kopassus officers were the overall organizers of the militia campaign, it must be recognized that the army as a whole was behind the militias.

In their public statements, army officers alternated between two contradictory justifications for the militia violence: a) the militias were independent organizations spontaneously formed by pro-Indonesia East Timorese outside of all governmental control; and b) the army had organized civil defense squads for legitimate reasons of "public security." ${ }^{25}$ In accordance with the second storyline, the army arranged for the Aitarak militia to be recognized as the official civil defense organization for the Dili district in May 1999-only two weeks after Aitarak had rampaged through the streets and killed unarmed civilians. The documents recognizing Aitarak as a Self-Created Security Force (Pengamanan Swakarsa) reveal that Aitarak was indeed a full-fledged institution of the government. The documents were signed by the district head (the bupati), Domingos Soares. On Aitarak's board of advisors sat the Korem commander and the governor. Its head was the mayor (walikota) of Dili and the vice-heads were the Dili Kodim vice-commander and deputy police chief. The visible East Timorese leader of Aitarak, Eurico Guterres, was merely responsible for implementing the plans on the ground: he was the Operational Field Commander. The government had sixty pages of computer print-outs listing the names, addresses, and occupations of nearly 1,500 purported Aitarak members. ${ }^{56}$ The government knew that some of its civil servants were involved in Aitarak. Guterres sent his superiors in the military and the

\footnotetext{
54 National Commission on Human Rights, "Executive Summary of the Report of the Commission of Investigation into Human Rights Violations in East Timor," January 31, 2000.

55 The former explanation was favored when the officers appeared before the National Human Rights Commission inquiry into the East Timor violence. Jakarta Post, "Indonesian military admits 'routine meetings' with militia," December 28, 1999. But the latter was frequently expressed in the months before the vote. See, for example, the quotes of various officers in the report by the East Timor International Support Center, "Indonesia's Death Squads: Getting Away with Murder," Occasional Paper no. 2 (Darwin: East Timor International Support Center, May 1999).

56 Pemerintah Kabupaten Daerah Tingkat II Dili, Pengamanan Swakarsa (PAM Swakarsa) dan Ketertiban Kota Dili (Dili, May 1999). One suspects that many of the 1,452 men listed as Aitarak members were not actual members, but rather men the militia had pressured into becoming members. Aitarak never drew more than half that many men at its rallies, usually far less.
} 
government a list of thirty-seven names of civil servants with the request that they be granted leave from their work to devote more time to Aitarak. ${ }^{57}$

The fact that the army never settled upon a consistent storyline ruined the illusion of "civil war." In speaking about the militias, the army clearly did lie; it often denied that it was providing weapons and money and granting wide license to the militias. When the army officers had to lie consciously, instead of asserting the lies they believed to be truths, they proved to be utter failures. To flabbergasted foreign journalists, they frequently claimed that the militias were spontaneously formed, outside of all official control, even as other officers admitted giving weapons to them and the militia leaders themselves admitted to being paid by the army. ${ }^{58}$

\section{The Decision to Hold a Referendum}

The civil war strategy, as a response to the expansion of the resistance in 1998, was already underway prior to the decision of President Habibie's cabinet, announced on January 27, 1999, to give the East Timorese an opportunity to vote on whether to remain in Indonesia or become independent. It is often alleged that the decision to hold a vote in East Timor was pushed through the cabinet by President Habibie against the will of the military, which then set about sabotaging the vote by further unleashing the militias. ${ }^{59}$ This does not appear to have been the case. If the military had genuinely opposed Habibie's proposal to hold a vote, one would expect it to have resisted more forcefully. The military was well represented in the cabinet and could have squelched the proposal. It is now clear that the generals decided to go along with Habibie's proposal because they thought they could win the vote. The then Foreign Minister, Ali Alatas, has recalled that all the ministers in the cabinet were confident: "We were then very convinced we would win the referendum. Everything was painted with optimism. ${ }^{\prime 60}$ One reason cabinet members were confident was that they thought the recently mobilized militias would be able successfully to intimidate the electorate. A leaked memo of July 1999, written by an assistant of the powerful Coordinating Minister on Politics and Security, Gen. Feisal Tanjung, indicated that the government had been initially optimistic that "autonomy would be the people's choice" since the "pro-integration groups" (meaning the militias) had, in the early months of 1999, been able to "reverse the situation" of the previous year and "become dominant very quickly." 61

${ }^{57}$ Eurico Guterres surat kepada Walikota, "Permohonan Dispensasi," Mei 26, 1999.

58 One of the best journalists covering East Timor in 1999, John Martinkus, has described the Indonesian army's unconvincing attempts to hide its role in leading the militias. See John Martinkus, A Dirty Little War (Sydney: Random House, 2001).

${ }^{59}$ For instance, John McBeth's dispatch from Jakarta, "Second Thoughts," Far Eastern Economic Review (April 29, 1999). Also, Damien Kingsbury, "East Timor to 1999," in Guns and Ballot Boxes, ed. Damien Kingsbury (Clayton: Monash Asia Institute, 2000), p. 27.

${ }^{60}$ Interview with Ali Alatas, Tempo, September 18-24, 2000. Also see the interview with Alatas in Jakarta Post, November 2, 1999. There he stated: “Up to the balloting, the reports we got from our people, of the prointegration people, including Lopez da Cruz and so on, is that we were going to win."

61 The memo was written by the assistant coordinating minister of politics and security, H. R. Garnadi. This four-page memo, dated July 3, 1999, was leaked almost immediately. The government claimed the document 
Gen. Tanjung himself, in his authorized biography, has stated that the military first estimated that about 75 percent of the East Timorese would vote in favor of integration. He and his fellow officers interpreted the fact that 80 percent of the East Timorese electorate participated in the Indonesian election of June 7, 1999 as confirmation of their estimate: "This was a strong indication that the majority of the East Timorese were siding with Indonesia." ${ }^{62}$ The results of the June election were actually unreliable; the local government was too busy with the upcoming United Nations vote to conduct it properly, and few East Timorese bothered to vote. Absurdly enough, Tanjung based his assessment of the desires of the East Timorese upon these falsified results. Here one can see how different branches of the government, each engaged in deceptive practices, can wind up fooling each other.

Given that Gen. Tanjung was the senior military figure within Habibie's cabinet, it is likely that he played a crucial role in the cabinet's decision to approve President Habibie's proposal to put Indonesian sovereignty to a vote in East Timor. It should be noted that he had prior experience in engineering the results of similar kind of referendum in West Papua and deceiving the United Nations. He served as the army's point man for the covert operations behind the 1969 "Act of Free Choice" in West Papua. As described in his authorized biography, Tanjung led 150 soldiers of RPKAD (the special forces that were later named Kopassandha, and then Kopassus) in a secret operation to win the referendum on independence in West Papua. He assigned his soldiers to "work on" (menggarap) the members of the 1,026-member council of West Papuan representatives. Each soldier attached himself to six representatives and plied them with food, cigarettes, and drinks. Tanjung recalled: "All the members of the council were continually contacted and managed up to the day before the vote. So, we were always on them." He admits he tried to keep the operation hidden from the United Nations observers so that they would not suspect the referendum was anything less than fair. ${ }^{63}$ Gen. Tanjung's success in determining the outcome of the West Papuan vote in 1969 may have led him to believe that the army could repeat such a success thirty years later in East Timor. Although the East Timor voting process was completely different - it was tightly controlled by the United Nations and enfranchised all adults, not just a select group of representatives-Tanjung may have assumed that the army's power over the society was sufficient to guarantee an Indonesian victory. Even if the polling booths were controlled by the United Nations, the East Timorese society was still under the control of the army.

One cannot understand the army's actions in 1999 without recognizing that the officer corps firmly believed that many of the East Timorese constituted a "floating

was a forgery. The foreign ministry spokesman in East Timor, Dino Patti Djalal, told journalists that the stamps, signature, and index numbers were all incorrect. (Agence France Press, "Leaked Document '100 percent fake,"' July 21, 1999.) Much to Djalal's embarrassment, Garnadi later admitted before the National Human Rights Commission enquiry team that the stamps, signature, and index numbers were indeed correct. He claimed, unconvincingly, that the text of his memo had been somehow forged. "Team: Document on Timor Burning Valid," Indonesia Observer, December 29, 1999.

62 Usamah Hisyam, Feisal Tanjung: Terbaik untuk Rakyat, Terbaik untuk ABRI (Jakarta: Dharmapena, 1999), p. 738. I thank Bob Lowry for informing me of this book.

63 Usamah Hisyam, Feisal Tanjung, pp. 219-232, 724. For further discussion of the "Act of Free Choice," see John Saltford, "United Nations Involvement with the Act of Self-Determination in West Irian (Indonesian West New Guinea), 1968-1969," Indonesia 69 (April 2000): 71-92. 
mass," a collection of apolitical, ignorant peasants, who could be alternately intimidated and cajoled into voting in favor of integration. ${ }^{64}$ If the army had not been thoroughly deceived by its own myths about the stupidity and malleability of the East Timorese, it would not have allowed the vote to take place or would have arranged a very different pre-ballot scenario. The fact that the leading Indonesian government and military officials believed that they could win the vote proves that they did not understand the thinking of the East Timorese people after twenty-four years of occupation and innumerable intelligence reports.

Following the announcement of January 27, the military began directing and shaping the militias in ways that not only helped generate the appearance of a civil war, but also promised to help secure an electoral victory. As Indonesia's negotiations with Portugal and the United Nations were coming to a conclusion in March and April, the army decided to launch a major wave of militia violence. It was the last opportunity for a large-scale terrorization of the electorate before the United Nations personnel arrived in May. Tomas Goncalves, a longtime collaborator and former head of Ermera district, has claimed that the army gathered all the militia leaders in Dili for a meeting on March 26. They planned a sweeping operation to kill off independence supporters, including church officials. At that point, Goncalves believed that the cost of collaboration had become far too high and fled to Macau. ${ }^{65}$ Another former highranking civilian collaborator, Vincente Tilman, informed me that he had attended meetings with Kopassus and army intelligence officers in February 1999 and was invited to join the militia campaign. He refused to cooperate, telling the officers that their militias did not have popular support and would not succeed in winning the vote for Indonesia. ${ }^{66}$

Part of the government's strategy for winning the vote was to demand the support of the East Timorese civil servants; this resembled the strategy the New Order government had followed when it used to rely on civil servants for the electoral victories of the government's own political party, Golkar. ${ }^{67}$ The army was worried that many civil servants, even at the highest levels, supported independence. In April 1999, the commander of the Dili Kodim compiled a list of 226 civil servants in Dili whom he suspected of being involved in the resistance. He listed their names, job positions,

\footnotetext{
64 The spokesman of the militias, Basilio Araujo, shared the arrogance of his Indonesian superiors: "the majority of people who actually do not know anything about politics, who actually do not care about politics. Sixty percent are illiterate, so how can one claim that the majority of the East Timorese people want for an independence, or for an integration, or for whatever? [sic]" Radio Australia, March 1, 1999. On another occasion he said, "Actually 10 percent of the population are politically aware, 90 percent are just peasants or fishermen, and they do not want to think politics." Agence France Press, "A Campaign to Liquidate the Resistance in East Timor," April 19, 1999.

65 Radio Netherlands Gema Warta, October 6, 1999. Expresso (Portugal), "Orders to Kill," September 11, 1999.

66 Personal interview, Dili, August 1999. Vincente Tilman was a member of the Apodeti party, former district head of Ambeno, and former representative to the MPR legislative body in Jakarta. He was one of many former collaborators who supported independence in 1999. His house was burned down and his family put to flight by the militias after the vote.

67 The Minister of Information in President Habibie's cabinet, Yusus Yosfiah, visited East Timor and threatened that civil servants suspected of supporting independence would be dismissed. Agence France Press, July 12, 1999.
} 
address, and his judgments on whether they were each a "radical," a "provocateur," an "activist," or merely "involved." 68

The hardened souls who were left, who showed themselves willing to participate in murderous violence against East Timorese civilians, were those such as the Kopassus trainees of Gada Paksi, Eurico Guterres, entrusted by the army to lead the Aitarak militia for the crucial Dili district, and Manuel de Sousa of Liquisa's Besi Merah Putih. These two militias led the final large-scale terror campaign prior to the signing of the United Nations agreement on May 5. Besi Merah Putih, with the logistical support of the Liquisa Kodim, massacred many of the refugees sheltering in the Liquisa church compound on April 6. About two hundred helpless refugees, women and children included, were hacked and stabbed to death. ${ }^{69}$ Then, on April 17, a collection of about two thousand militiamen from all over East Timor gathered in Dili for a rally in the plaza in front of the governor's office. ${ }^{70}$ As the top military and civil officials of East Timor sat in attendance, Eurico Guterres told the crowd to capture independence leaders dead or alive. After the rally, the militias roamed the city and terrorized the residents. They destroyed the offices of the daily newspaper Suara Timor Timur that, while loyalist, had favored the disbandment of Gada Paksi the year before and had not shown a whole-hearted commitment to the militias' terror strategy. They burned down the house of a family who had led a mass funeral for their son, Herman das Soares, after he had been shot and killed by soldiers of a BTT post on June 16, 1998. The militias specifically targeted the residences of resistance leaders. That none were killed can be attributed to the fact that they had either gone into hiding or taken shelter with the police and military. The militias killed fifteen people, mainly refugees, who were staying at the home of one independence leader, Manuel Carrascalao. Reporters in Dili estimated the death toll during the rampage on April 17 and the following days at around thirty.

${ }^{68}$ Lt. Col. Priyanto, Commander Kodim 1627, April 28, 1999 (Secret). This list was sent to the commander of the Korem, Col. Tono Suratman.

${ }^{69}$ Yayasan HAK's preliminary investigation immediately after the massacre, when the survivors were in hiding and difficult to locate, documented the names of fifty-seven persons killed. Press reports at the time estimated the total number killed to be around two hundred. See, Peter Carey, "The False Dawn," The World Today 55,5 (May 1999): 14-15. The United Nations Transitional Administration uncovered many gravesites in Liquisa in late 1999 and early 2000. A police official believes the number of victims may be over two hundred. Lusa News Agency, "More than 200 Killed a Year Ago in Liquiça," April 6, 2000.

${ }^{70}$ The Dili district Kodim, in its monthly report for April, listed the number of men attending the rally from the various district militias. Kodim 1627, "Laporan Bulanan 1-30 April 1999." The numbers are perhaps inflated.

$\begin{array}{lr}\text { Aitarak (Dili) } & 760 \\ \text { Besi Merah Putih (Liquisa) } & 400 \\ \text { Laksaur (Suai) } & 75 \\ \text { Mahidi (Ainaro) } & 75 \\ \text { Ahi (Aileu) } & 80 \\ \text { Naga Merah (Ermera) } & 75 \\ \text { Morok (Manatuto) } & 80 \\ \text { Alfa (Lospalos) } & 50 \\ \text { Saka (Bacau) } & \underline{50} \\ \text { Total } & 1,645\end{array}$


The Kodam IX commander in Bali, Maj. Gen. Adam Damiri, was encouraged by the April 17 attack. He later wrote in an internal report that the majority of East Timorese became loyal supporters of Indonesia after April 17 because they could see that the pro-integration side had many supporters. ${ }^{71}$ The army's erroneous presumption had always been that whatever mass support the resistance enjoyed was due to deceit and intimidation: the small clique behind the resistance fooled ordinary East Timorese with anti-Indonesian propaganda and, when that was not effective, forced them at gunpoint to support the resistance. Within Damiri's logic, the purpose behind the militia show of force in Dili on April 17 was to embolden ordinary East Timorese to stand up to the intimidation tactics of the resistance.

The Kodim intelligence report on the April 17 terror reflects a commitment to describe events according to the myths of the army's own propaganda. The unilateral militia violence of April 17 was presented as self-defense against attacks from the "anti-integration" group. Kodim intelligence reported that the militias, while parading through the streets, were shot at and stoned in the neighborhood of Balide and in the area around Herman das Soares's house. These two (fictitious) attacks were assumed to be sufficient justification for the militia violence throughout the city "all along the route they passed through." The intelligence report does not mention most of the incidents of militia violence and does not explain exactly how, according to its figures, "thirteen anti-integration persons died and five were seriously wounded." The details of the violence were left obscure so that the army's mendacious explanation- "fighting between the pro and anti-integration groups" - could remain plausible. ${ }^{72}$

This version of the April 17 violence filtered its way up the army hierarchy and ultimately appeared in a confidential briefing booklet issued by the intelligence office of military headquarters in Jakarta. This booklet, meant as an overview of national political issues, was distributed to military offices throughout Indonesia and thus became the army's "true report" of the event. According to this intelligence briefing, the violence on April 17 was merely "a physical clash between the two sides" that had been twisted and exaggerated by the foreign media. The army believed there was a conspiracy to "shape public opinion abroad that the security situation in East Timor is in an uncertain condition and will impact the process of peaceful resolution now being discussed at the international level (the United Nations). ${ }^{\prime 73}$

The Dili Kodim's monthly intelligence reports of 1999 were full of similar distortions. One feels, while reading through these secret reports from January to July 1999, a strange sense of unreality. Every incident of the militia's unilateral aggression on unarmed civilians was either reported as a clash between the two rival political forces or not reported at all. Meanwhile, every act of violence, either real or fictitious, against the militias was recorded in detail. One would imagine from these reports that

${ }^{71}$ Maj. Gen. Adam Damiri, to the Minister for Politics and Security, "Perkembangan Situasi dan Kondisi Wilayah Timor timur menjelang Penentuan Jajak Pendapat, Dili," July 1999. This document is not in the HAK Collection. It was obtained by the National Commission of Human Rights' commission of inquiry in late 1999.

72 Kodim 1627 Staf Intelijen, "Laporan Bulanan Pengamanan TNI-AD Periode 1-30 April 1999" (Dili, Secret).

73 TNI Headquarters, Intelligence Center, Masalah Aktual, PAM tubuh TNI-AD dan Asistensi Teknis Bidang Intelijen (Jakarta, May 1999; Secret), pp. 11-12. 
the Indonesian side was always on the receiving end of the violence in Dili. For instance, of the nine incidents the Kodim reported for July, six of them involved threats and acts of violence against militia members, soldiers, or policemen. The other three cases were reported as entirely unconnected to the so-called "civil war." The Kodim did not report a single attack by the militia or the Indonesian security apparatus for the entire month. Indeed, the Kodim argued that they displayed remarkable restraint in the face of a conspiracy to provoke "the military and the integration forces into irregular actions that could be exposed in international forums."

Even if the officers writing the Kodim reports knew the truth of the matter-that the militias were terrorizing a populace offering no resistance-their reports might have led other officers to misperceive that truth. With so many intelligence agents hewing to the propaganda line and reporting falsehoods for so many months, the army officers in Dili, Denpasar, and Jakarta must have been at the very least confused when attempting to determine the truth about specific incidents. The leading officers knew full well that the army was funding and arming the militias to intimidate voters, but they may have put full faith in their intelligence reports and believed that the episodes of violence were clashes between two sides, not unilateral attacks by the militias. At the moment when the army was under close international scrutiny, it remained trapped within its self-woven webs of deceit.

By July, the military was having second thoughts about the militia strategy of intimidating the electorate. Through the haze of their preconceived notions on the malleability of the East Timorese, officers of the high command could still sense that the militia strategy was not producing a timid and loyal electorate. The leaked Garnadi memo marked this reassessment. Garnadi, reporting back to Gen. Feisal Tanjung, the coordinating minister of politics and security, observed that the initial confidence of Indonesian officials that they would win the vote had begun to waver once the United Nations personnel arrived in May. ${ }^{75}$ The "anti-integration group" had become emboldened once more. The government's optimism "became less certain." Garnadi proposed a new strategy since the presence of the United Nations and international observers made it difficult to continue violent attacks on the resistance ("our room for movement has been limited"). The new strategy he recommended was to buy the voters sympathy-to drop the stick and pick up the carrot. Following the typical

\footnotetext{
${ }^{74}$ Kodim 1627 Staf Intelijen, "Laporan Bulanan Pengamanan TNI-AD Periode 1-31 July 1999" (Dili, Secret). Another clear case of the Kodim's falsification of the facts is the case of the murder of Benedito de Jesus on February 14, 1999. The Kodim intelligence reported that Benedito was killed when the Mobile Brigade police clashed with a crowd of anti-integration people attacking the house of an East Timorese sergeant in Barropite neighborhood. Kodim 1627 Staf Intelijen, "Laporan Bulanan Pengamanan TNI-AD Periode 1-28 Februari 1999," (Dili, Secret). The actual story, recorded by journalists who arrived on the scene immediately afterwards and photographed the corpse, was that a group of Mahidi militia had rampaged through the neighborhood. Chased by the local residents, the militia fled into the Mobile Brigade police headquarters. Someone from inside the headquarters, either a militia member or a policeman, fired into the crowd gathered outside. That was when Benedito was hit. The funeral procession for him two days later, filmed by journalists, was attended by countless thousands of Dili residents, perhaps as many as twenty thousand. See the TV documentary, "A License to Kill," Australian Broadcasting Corporation (aired on March 15, 1999); the transcript is available at the website: www.abc.net.au/4corners. The Kodim reported a paltry 1,800 people in the funeral procession.

75 See footnote 61 , above.
} 
official view that most East Timorese were merely mindless brutes with no political consciousness, he opined:

The task of winning Special Autonomy for the people of East Timor is actually not too difficult since what is being fought over is a floating people [rakyat mengambang] whose demand is very simple: the supply of food and medicine. The people will follow whoever can provide food and medical treatment. ${ }^{76}$

The new threat perceived by the government was not the clandestine resistance but the Non-Governmental Organizations (NGOs) providing food aid to the tens of thousands of refugees that the militias had generated: "In Dili at this point there are thirty-two NGOs ready to help the 'refugees." Garnadi naively believed the government could turn the tide if it organized its officials and civilian supporters to distribute food and medicine.

Garnadi's interpretation of ABRI's thinking corresponds with Gen. Tanjung's published account. Gen. Tanjung recalled that ABRI's first estimate of 75 percent in favor of integration with Indonesia was revised downward sometime later (probably around late June to early July) to 47.6 percent. ABRI believed that the United Nations personnel were encouraging the East Timorese to choose independence. The revised estimate was that 37.1 percent of the populace were decidedly against Indonesia while the rest, 15.3 percent, constituted the proverbial "floating mass" (massa mengambang). Tanjung's office believed that the military could win over most of this "floating mass" in the final weeks before the vote by doling out food and medicine, in an action the army named Operation Sympathy, and raise the figure of the pro-Indonesia vote to 56 percent. ${ }^{77}$

Attaching new and urgent importance to humanitarian aid, ABRI began a twopronged strategy in early July: attacking the NGOs and promising to distribute its own aid. A convoy of NGO aid workers returning from refugee settlements in remote parts of southern Liquisa district was assaulted by the Besi Merah Putih militia on July 4. Several were stabbed, and all were forced to flee for their lives. Many of their vehicles were vandalized by the militia and later confiscated by the district police. ${ }^{78}$ Soon after the attack, the governor, Abilio Soares, announced a new initiative to deliver food aid to refugees. ${ }^{79}$ The Kodam chief of staff, Brig. Gen. Mahidi Simbolon, wrote a memo to Gen. Wiranto on July 6 to ask for Navy boats so that the military could transport rice to East Timor. In words very similar to Garnadi's, he wrote: "Regarding the implementation of the ballot, there are already thirty-five NGOs, Indonesian and foreign, that are delivering rice to the people. This situation will have an effect on results of the voting. Because of this, the provincial government of East Timor

\footnotetext{
76 A translation of the document and images of the original Indonesian-language text (from xeroxed pages) can be found at the website: http://etan.org/vtibin/shtml.exe/news/news $99 \mathrm{~b} / \mathrm{secret} 2$.htm/map.

77 Usamah Hisyam, Feisal Tanjung, pp. 738-739.

78 International Federation for East Timor Observer Project, "Report on the Militia Attack on the Humanitarian Team in Liquiça," July 8, 1999. Military headquarters in Jakarta tried to discredit the humanitarian aid workers by claiming that they had given aid only to "pro-independence refugees" and had escorted three armed members of Falintil. Kompas, July 6, 1999, p. 1.

${ }^{79}$ Kompas, July 16, 1999, p. 18 . Soares promised to build seven thousand houses for refugees in Liquisa and provide food, clothing, and medicine.
} 
immediately needs to distribute rice to the people. ${ }^{\prime 80}$ Despite its intention to buy sympathy, the military did nothing to distribute humanitarian relief in July and August. Right up to election day, it was stuck with the militia strategy of intimidation. Perhaps it did not have enough money for such charity. After all, the military had initially attempted to pay the militias with counterfeit money. When that did not succeed, it appropriated the entire 1999 budget for East Timor's civil administration. After March 1999, the provincial government did not have any money for food aid; all of it went to the militias. ${ }^{81}$

Even if the government had done more to distribute aid, one can confidently assert that the results of the ballot would not have been affected. The East Timorese were not mindless brutes who obeyed whoever gave them food. One poor East Timorese man, ravenously eating a meal handed out at a pro-integration rally in August, told a colleague of mine that he would gladly eat whatever food the pro-integration side proffered but would vote for independence: "My stomach is pro-integration but my heart is pro-independence."

The mood of the Indonesian government's high officials turned pessimistic in July and August. They sensed that defeat was a distinct possibility. A Foreign Ministry spokesman in Jakarta estimated in early August that Indonesia would win only 51 percent of the votes. ${ }^{82}$ The police in Dili wrote up a secret intelligence report in August that acknowledged, in a rare moment of candor, that the members of the resistance had "a sense of belonging, a powerful organization, and consistent stand in building and defending their group." 83 The mass base of the resistance had "a determined and high spirit of struggle that is based on instincts of courage, tenacity, and persistence to struggle for/defend the existence of itself as a group. ${ }^{184}$ Police intelligence viewed the pro-Indonesia side as the exact opposite: the leaders were a loose collection of opportunists who were "not well-organized" and solely motivated by "economic status." The mass base of the pro-integration group was "unstable and inconsistent in taking positions so that it is easily influenced." The leaders were "not concerned to follow through with decisions and plans already laid out." Police intelligence denounced the militia leaders, hailed in the Indonesian press as noble patriots, as selfish power-mongers: "Egocentric attitudes and the desire for winning for individual self-interest are still dominant among the figures and leaders." Whereas the members of the resistance sacrificed themselves for their ideals and worked closely with other members, the pro-Indonesian side consisted of venal status-seekers lacking committed followers. ${ }^{85}$ The police report's high praise of the resistance leaders was actually a way

\footnotetext{
80 Brig. Gen. Mahidi Simbolon to Panglima TNI, "Pengajuan dukungan Kapal Laut TNI AL Jenis Frost" (Denpasar, July 6, 1999; Secret).

81 On the financing on the militias, see the report by Mark Davis for the Australian television show "Dateline" on the SBS network, February 16, 2000.

82 "Indonesian Ministry holds out 'slim' hope of winning Timor vote," Agence France Press, August 9 , 1999.

${ }^{83}$ Kepolisian Negara Republik Indonesia Daerah Timor Timur, Rencana Operasi "Hanoin Lorosae II" (Dili, August 1999; Secret), "Perkiraan Keadaan Intelijen Kepolisian Khusus tentang Manghadapi Kontijensi Opsi I dan Opsi II di Polda Timor Timur," p. 4.

84 Ibid.

85 Ibid.
} 
of demeaning the East Timorese people. If Indonesia lost the vote, police intelligence assumed it was because the core group of pro-independence leaders was more committed and intelligent than Indonesia's collaborators in winning over the "floating mass," not that the East Timorese themselves were determinedly opposed to Indonesian rule because of the years of torture and killing. In analyzing why Indonesia might well lose the vote, police intelligence remained trapped within the long-standing myth that portrayed the East Timorese as ignorant and backward.

\section{Evacuation}

As soon as the Indonesian government signed the agreement with Portugal and the United Nations on May 5, 1999, it began drawing up contingency plans for the postballot scenario. We have enough documentation to understand the basic outlines of the planning for the territorial troops. It is clear that the Indonesian military had no intention of fulfilling the government's pledge to the United Nations and Portugal to provide security after the ballot regardless of the result. In case independence was chosen, the military was not planning on "a peaceful and orderly transfer of authority in East Timor to the United Nations," as the May 5 agreement stipulated. ${ }^{86}$ It was secretly planning for chaos. It drew up a detailed plan for quickly evacuating foreigners, Indonesian civilians, Indonesian soldiers, and East Timorese. This was the plan that was implemented in early September.

The Vice Chief of Staff of the army, Lt. Gen. Johny Lumintang, sent a telegram to the Kodam commander on May 5 that instructed him to develop "a plan for moving to the rear/exodus if the second option [independence] is chosen [rencana pemindahan ke belakang/pengungsian apabila opsi kedua menjadi pilihan]. ${ }^{187}$ Sometime after receiving Lumintang's order, Kodam IX developed a plan titled Operation Withdrawal (Operasi Cabut). Unfortunately, we do not have the text of this operation, only references to it in other documents. Under the authority of the Kodam's plan for withdrawal, the Korem for East Timor developed a plan for a post-ballot evacuation titled Operation Wira Dharma-99. The East Timorese police developed a similar plan titled Operation Hanoin Lorosoe II. The HAK Collection has some of the documents pertaining to the Korem's plan and the full text of the police's plan.

The Korem's Operation Wira Dharma-99 was a plan drawn up in July to evacuate the soldiers and policemen of the territorial structure, their families, Indonesian citizens, and pro-integration East Timorese. The Korem estimated how many people would be evacuated from each district, determined the land, sea, and air travel routes, and calculated the number of trucks and liters of gasoline that would be required. This would have been a large-scale undertaking even if it was exclusively designed for the soldiers of the territorial structure along with their wives and children $(26,000)$ and the Indonesian citizens resident in East Timor $(43,000)$. What was remarkable about the

\footnotetext{
86 Agreement between the Republic of Indonesia and the Portuguese Republic on the Question of East Timor, May 5, 1999, article 6. Also see the East Timor Popular Consultation Agreement regarding Security signed by Indonesia, Portugal, and the Secretary-General of the United Nations on May 5, 1999.

87 Lt. Gen. Johny Lumintang, Surat Telegram kepada Pangdam IX, May 5, 1999.
} 
Korem's plan was the ambitious intention to transport 180,000 East Timorese into West Timor. ${ }^{88}$

The role of the police in this evacuation process is spelled out in the police's planning document for what it called Operation Hanoin Lorosae II. (Hanoin Lorosae is Tetun for "Think East Timor.") The police were assigned the task of "safeguarding" the evacuation routes and the state assets. The primary function of the police was to escort foreigners and ensure that none of them, especially the VIPs, was harmed. The planning document repeatedly mentions this function as if it was the number one priority of the police during the post-ballot period. The basic description of the police's responsibility by the Police Chief for East Timor, Col. G. M. Timbul Silaen, mentioned the vaguely general task of "bringing the security situation under control" and the very specific task of "escorting and safeguarding" the people being evacuated out of East Timor. ${ }^{89}$

The military's explicit expectation, as found in the police document, was that the pro-integration East Timorese would run amok if the vote went against them, and the implicit assumption was that the military would not stop them. The police intelligence report described the following post-ballot scenario if the independence option won:

If the East Timorese people reject wide-ranging autonomy (the pro-independence side wins), the pro-Integration group will be disappointed and frustrated, especially when they have taken for granted that they will be victorious since they have received so much moral and material support from the Indonesian government. The disappointment and frustration will lead to anarchic and destructive attitudes, confrontational/savage ... Such a situation will result in many people fleeing to places that they consider safe. ${ }^{90}$

The police calculated how many people would be evacuated if the independence option was chosen by the majority of voters. It also calculated the number to be evacuated if the autonomy option was chosen. It is highly unlikely that the military would have evacuated supporters of independence after an Indonesian victory, yet the police did draw up a plan on paper for such an evacuation. Without informing the United Nations, the police were planning on transporting between 184,000 to 259,000 people out of East Timor regardless of the results of the vote. ${ }^{91}$ The police and the Indonesian military continued to assure the United Nations that it would be able to provide sufficient security after the ballot even as their internal documents spoke of uncontrollable chaos and of plans to move a large portion of the population out of East Timor instead of trying to protect them within East Timor.

\footnotetext{
88 Korem 164, Rencana Operasi "Wira Dharma-99," appendix D, "Rencana Banmin."

${ }^{89}$ Kepolisian Negara Republik Indonesia Daerah Timor Timur, Rencana Operasi "Hanoin Lorosae II," (Dili, August 1999; Secret), p. 1.

90 Kepolisian Negara Republik Indonesia Daerah Timor Timur, Rencana Operasi "Hanoin Lorosae II" "Perkiraan Keadaan Intelijen Kepolisian Khusus tentang Manghadapi Kontijensi Opsi I dan Opsi II di Polda Timor Timur," pp. 9-10. This police assessment followed the military's propaganda that the militias were independent, when, in fact, the militias did not launch the scorched earth operation on their own initiative.

91 Kepolisian Negara Republik Indonesia Daerah Timor Timur, Rencana Operasi "Hanoin Lorosae II."
} 
One key to understanding the military's planning for the post-ballot scenario is the document that we do not yet have-the document for Kodam IX's Operation Withdrawal (Operasi Cabut). It contains a statement of the general policy that guided the Korem and the East Timorese police in formulating their own planning documents. We know from a telegram sent by the Dili Kodim commander to the Korem commander that Operation Withdrawal began on September 6, 1999 at three o'clock in the afternoon. ${ }^{92}$

The plan for the evacuation was, if taken at face value, obviously inconsistent: the army was to withdraw all of its territorial troops from East Timor even though it predicted there would be wild violence that would presumably require as many troops as possible to contain it. Indonesia proudly asserted after the vote that East Timor was still under its sovereignty and that it was fully responsible for security there. The army put itself in the strange position in early September of simultaneously withdrawing and introducing troops. Within two days after Operation Withdrawal had taken effect, Gen. Wiranto sent five new battalions to East Timor, supposedly to stop the violence. ${ }^{93}$ Lacking detailed documentation, it is difficult to discern the strategy behind the evacuation plan. The army's strategy may have been to create a base in West Timor for prolonged warfare against East Timor. The Indonesian government, as noted above, had been hoping the vote would be close, at the very least, so that even if the resistance won Indonesia would have an apparent justification for partitioning East Timor and retaining the western half. The government must have also hoped that the demographic weight of the civilians forcibly deported to West Timor would lend credence to Indonesia's claim to the western half of East Timor. ${ }^{94}$

Since the territorial troops were ordered to withdraw and to handle the evacuation of civilians, the scorched earth campaign appears to have been the primary responsibility of the non-organic troops. From eyewitness accounts collected by HAK Foundation, it is clear that the territorial troops and policemen looted, burned, and killed as they pulled out of their towns and made their way to West Timor. If forced deportation was the task assigned to the territorial troops, the assignment of looting property and destroying buildings was largely left to the non-organic troops who remained in East Timor with many of the militia members. It is possible that there was no written order for the post-ballot scorched earth campaign and that orally communicated orders to the leading commanders were sufficient. A detailed analysis of the army's post-ballot war crimes in East Timor and the identification of officers most responsible has to be based primarily upon sources other than the documents in the HAK Collection.

\footnotetext{
92 The quote is: "Operasi Cabut Rem 164/WD yg berlaku mulai 061500 Sep 1999 Wita." Telegram from Lt. Col. Soedjarwo, Komandan Kodim 1627, to Dan Rem 164, September 7, 1999. The Kodim commander reported that the first batch of Kodim soldiers evacuated Dili on September 7 at nine in the morning, leaving for Kupang in seven trucks.

93 "Jakarta Concedes a Loss of Control," New York Times, September 12, 2000.

${ }^{94}$ Hamish McDonald, "Time to Accept the Game's Over," Sydney Morning Herald, September 30, 1999.
} 


\section{Conclusion}

Indonesia's army of occupation in East Timor conformed to the general pattern of colonial armies: its officers had an illusion of permanence, a conviction in their mental superiority, and an inability to believe that the subject population had a principled and passionate desire for independence. They consistently imagined the East Timorese to be malleable persons who, if intimidated and terrorized, would meekly submit instead of harboring a deep-seated hatred of the army and searching relentlessly for secretive ways to resist. Their underestimation of the rationality and humanity of the East Timorese was so complete and their confidence in their capacity to control the populace so high that the army generals willingly agreed to put Indonesia's sovereignty to a United Nations-administered vote in 1999. It was fortunate for the East Timorese-nearly 80 percent of whom voted for independence-that the army had deceived itself so thoroughly on its prospects for success at the ballot box; otherwise, they might have never been given the chance to exercise their right of selfdetermination.

Although the result of the vote on August 30,1999 proved to be a humiliation for the army, there are few indications that it has abandoned its faith in its old myths. Since the vote, the army has maintained that the innocent East Timorese had been manipulated by wealthy foreign countries that promised them more material benefits than could be provided by crisis-stricken Indonesia. Gen. Feisal Tanjung, and many other officers, have blamed the United Nations for siding with the pro-independence side and rigging the results of the vote. ${ }^{95}$ The Minister of Defense in President Wahid's cabinet, Mahfud MD, claimed one year after the vote that the East Timorese had become so disappointed with the United Nations administration that they wanted to become part of Indonesia once more. ${ }^{96}$ Many Indonesian civilian leaders, not just the army brass, have refused to see the result of the vote as a genuine reflection of East Timorese desires and have sought to blame third parties for it. ${ }^{97}$ That Indonesia refuses to acknowledge its record of atrocities in East Timor is unexceptional-nation-states tend toward uncritical self-love-but this particular refusal to learn from the past is extraordinarily worrisome when the army is currently conducting similar counterinsurgency wars in Aceh and West Papua. Within the army, the belief in the efficacy of terror to solve political problems remains strong. The only lesson the army appears to have learned from East Timor is that a referendum on Indonesian sovereignty cannot be allowed to occur again.

\footnotetext{
95 Usamah Hisyam, Feisal Tanjung, pp. 715-740.

96 "Indonesian is Under Fire for Comments about Timor," New York Times, September 23, 2000. Mahfud was probably expressing the conclusion of the intelligence reports he was receiving.

97 "Australia the Bogeyman," Sydney Morning Herald, September 25, 1999.
} 